\title{
Cetacean populations on the SE Bering Sea shelf during the late 1990s: implications for decadal changes in ecosystem structure and carbon flow
}

\author{
Cynthia T. Tynan*
}

Department of Physical Oceanography, Woods Hole Oceanographic Institution, Woods Hole, Massachusetts 02543, USA

\begin{abstract}
Baleen whales typically migrate to high-latitudes to feed during summer in regions of predictably high concentrations of their zooplankton or fish prey. Therefore, their presence in shelf systems is a good indicator of productive food webs. Line-transect surveys of cetaceans conducted during the late $1990 \mathrm{~s}$ in the SE Bering Sea $\left(160.32\right.$ to $\left.171.08^{\circ} \mathrm{W}\right)$ indicate that the middle shelf $(50 \mathrm{~m}$ $<\mathrm{z}<100 \mathrm{~m}$ ) now supports the highest whale biomass in this region. In recent decades, whales were rare and hence their ecological role on the shelf was limited. During July 1997, the density and abundance (N) of humpback whales Megaptera novaeangliae and fin whales Balaenoptera physalus were highest on the middle shelf between 163.7 and $168.1^{\circ} \mathrm{W}: 0.0236$ humpback whales km${ }^{-2}, \mathrm{~N}=1308$ (coefficient of variation, $\mathrm{CV}=0.65)$, and 0.00924 fin whales $\mathrm{km}^{-2}, \mathrm{~N}=513(\mathrm{CV}=0.61$ ), respectively. Similarly, during June 1999, fin whales were the most numerically dominant species of large whale in the SE Bering Sea, with highest densities and abundance in the 'central' middle shelf $\left(163.7\right.$ to $\left.168.1^{\circ} \mathrm{W}\right)$ : 0.0169 fin whales $\mathrm{km}^{-2}, \mathrm{~N}=938(\mathrm{CV}=0.54)$. During the summers of 1997 and 1999, 65 and $79 \%$ of the prey consumption by fin whales in the SE Bering Sea occurred on the central middle shelf. Prey biomass consumed by fin and humpback whales on the SE Bering Sea shelf and slope in 1997 (264474 to 723504 metric tons, $\mathrm{mt}$ ) is equivalent to $34-94 \%$ of the 1997 echointegration trawl estimate of walleye pollock Theragra chalcogramma biomass (age 1+) for the shelf east of $170^{\circ} \mathrm{W}\left(0.77 \times 10^{6} \mathrm{mt}\right)$. Large whales were much more abundant on the middle shelf during the late 1990s than during preceding decades and, therefore, their foraging may have impacted trophic dynamics, carbon pathways and nutrient cycling. The partitioning of available carbon and energy in the pelagic and benthic systems of the shelf, as determined previously during the 1970s, when whales were rare, should now be reexamined relative to the increased ecological impact of these top-level predators. Fluxes of carbon that involve pathways through whales should be incorporated in shelf and oceanic carbon budgets.
\end{abstract}

KEY WORDS: Bering Sea $\cdot$ Carbon - Cetaceans $\cdot$ Coccolithophore $\cdot$ Ecosystem changes $\cdot$ Whales Resale or republication not permitted without written consent of the publisher

\section{INTRODUCTION}

Cetaceans and ecological changes in SE Bering Sea

Marine ecologists must contend with ecosystems from which many populations of top-level predators have been removed or severely depleted (Pauly et al. 1998, Baum et al. 2003, Myers \& Worm 2003), and one upper-trophic group in particular, marine mammals, has been shown to strongly influence the structure and function of communities (National Research
Council 1996, Bowen 1997, Estes et al. 1998, Springer et al. 2003). For instance, on the NW Atlantic shelf, cetaceans require an amount of fish and squid that exceeds the commercial harvest (Kenney et al. 1997). Baleen whales seek areas of highest prey biomass and density (Piatt \& Methven 1992, Kenney \& Wishner 1995) and, therefore, the distribution of foraging whales typically integrates the regional biomass of their principal prey (Macaulay et al. 1995, Wishner et al. 1995, Croll et al. 1998, Fiedler et al. 1998, Tynan 1998, Benson et al. 2002). Therefore, spatial or tempo- 
ral shifts in the distributions of whales can reflect pronounced change in the community structure and biomass of preferred prey species.

One marine ecosystem that has been well studied, and thus might provide insights into the ecological roles of cetaceans, is that of the eastern Bering Sea continental shelf. It is the second largest and among the most productive shelf systems in the world (Hood 1981, Coachman 1986, Walsh \& McRoy 1986), supporting one of the largest groundfish fisheries (Ianelli et al. 2000), and providing valuable habitat for many endemic and migratory species of top-trophic predators (Frost \& Lowry 1981, Hunt et al. 1981, Lowry \& Frost 1981, Ainley \& DeMaster 1990, National Research Council 1996, Tynan et al. 2001). An extensive ecological study of the SE shelf (PROBES Processes and Resources of the Bering Sea Shelf), conducted during the late 1970s and early 1980s, provided valuable insights into the structure and function of the ecosystem (Walsh \& McRoy 1986), albeit during a period when large whales were rare or absent (Kawamura 1975, Nemoto 1978, Leatherwood et al. 1983). PROBES established that the SE Bering Sea (SEBS) shelf is separated by 2 frontal zones into 3 distinct hydrographic and ecological domains: the well-mixed coastal domain of the inner shelf $(<50 \mathrm{~m})$; the 2-layer structure of the middle shelf $(50 \mathrm{~m}<\mathrm{z}<100 \mathrm{~m})$; and the outer shelf $(100 \mathrm{~m}<\mathrm{z}<180 \mathrm{~m}$ ) (Cooney \& Coyle 1982, Coachman 1986, Schumacher \& Stabeno 1998). The presence of the Middle Front at the $\sim 100 \mathrm{~m}$ isobath typically restricts the penetration of oceanic zooplankton onto the middle shelf, and separates distinct outer and middle shelf communities (Cooney 1981, Cooney \& Coyle 1982). During the PROBES era, when few whales were present in the SEBS, the middle-shelf food web was described as a primarily benthic system, in which most of the primary production was largely ungrazed and sank to the sea floor, supporting large standing stocks of epifaunal invertebrates (Walsh \& McRoy 1986). Conversely, the outer shelf was characterized as a more pelagic food web.

During the late 1990s, large-scale anomalies, such as the first-recorded extensive coccolithophore Emiliania huxleyi bloom indicated that the shelf ecosystem of the SEBS either had been or was becoming significantly altered (Vance et al. 1998, Hunt et al. 1999, Stockwell et al. 2001). The increase of foraging whales, and their presence within the E. huxleyi bloom on the middle shelf $(50<z<100 \mathrm{~m})$ in 1997, also suggested an altered ecosystem (Tynan 1999, Tynan et al. 2001). In the present paper, results of line-transect surveys of cetaceans, conducted during the late 1990s, provide estimates of abundance, stratified by shelf domains (i.e. middle shelf, outer shelf and slope) of the SEBS, from which to evaluate the current role of cetaceans in ecosystem structure and carbon flow, compared to the ecosystem of the 1970s and 1980s when few whales were present. The objective of the research was therefore to provide the main missing ecological link in the SEBS ecosystem, the cetaceans, placed in the context of oceanographic forcing and decadal-scale changes.

\section{Historical distribution and ecology of mysticetes in the SE Bering Sea}

During the 1950s, fin whales Balaenoptera physalus, humpback whales Megaptera novaeangliae, and North Pacific right whales Eubalaena japonica were abundant at the shelf-edge and Bering Slope Current region of the SE Bering Sea (Omura et al. 1969, Nasu 1974). The center of the fin whaling ground in 1954 to 1960 fluctuated within a small range, with peak catch at 54 to $55^{\circ} \mathrm{N}, 169^{\circ} \mathrm{W}$ in slope and basin waters (Nasu 1963). Whaling catch data from 1946 to 1975, compiled by the International Whaling Commission, also shows the highest concentration of fin whale harvest occurring off the shelf and along the shelf edge (Springer et al. 1999). This historical distribution coincides approximately with what is now called the 'green belt' (Springer et al. 1996). Whaling records attest to the removal of large numbers of whales from this region: e.g. shore-based operations in Akutan, Alaska took $\sim 3000$ fin whales and $\sim 3000$ humpback whales (1911 to 1929; Tønnessen \& Johnsen 1982, their Table 45), Japanese pelagic fleets took $>3000$ fin whales (1952 to 1961; Nemoto 1963 his Fig. 1), and still further numbers of whales were taken by Soviet whalers. By 1970, populations of large whales in the Bering Sea were decimated; however, except for aerial surveys during the early 1980s (Leatherwood et al. 1983), quantitative surveys during the 1970 s and early 1980s are lacking. Based on commercial whaling catch data, by 1975 whales were depleted through the subarctic North Pacific (Springer et al. 1999). It was at this time, that oceanographers and marine ecologists began to study and define the system from a processoriented approach (i.e. PROBES).

Historically, fin whales in the Bering Sea north of $58^{\circ} \mathrm{N}$ preyed mainly on fishes, whereas euphausiids were the dominant prey of fin whales in other regions of the northern North Pacific and Bering Sea (Nemoto 1959). During 1969 to 1979 , more than $65 \%$ of the stomachs of fin whales captured from May through August in the latter regions contained euphausiids (Kawamura 1982). Analyses of fin whales, captured from 1952 to 1958, showed that north of the Aleutian Islands they fed primarily on euphausiids (Thysanoessa inermis, $T$. longipes, $T$. spinifera, and $T$. raschii), followed by copepods (Neocalanus cristatus, 
N. plumchrus) and fishes (Nemoto 1959). For the same period, humpback whales fed primarily on euphausiids ( $T$. inermis, T. longipes, T. spinifera) and secondarily on fishes. During the 1950s, the shallow, neritic euphausiids $T$. raschii and T. spinifera were, at times, locally important in the diet (Nemoto 1959). In slope and basin regions of the SEBS, the copepod N. cristatus was an important prey of fin whales. With their decimation by whaling, the role of mysticetes in the carbon flow and trophic structure of the Bering Sea ecosystem was removed. The absence of whales is considered one of the factors responsible for large ecosystem shifts observed in the Bering Sea in the decades that followed (National Research Council 1996, Trites et al. 1999, Springer et al. 2003).

\section{MATERIALS AND METHODS}

Line-transect surveys of cetaceans were conducted simultaneously with the Alaska Fisheries Science Cen- ter's echo-integration trawl (EIT) midwater assessment surveys of walleye pollock Theragra chalcogramma on the eastern Bering Sea shelf and slope. Surveys were conducted from July 17 to August 5, 1997 and from June 7 to July 2, 1999, in the SEBS from outer Bristol Bay $\left(160.32^{\circ} \mathrm{W}\right)$ to the western side of the Pribilof Islands $\left(171.08^{\circ} \mathrm{W}\right)$ (Figs. $\left.1 \& 2\right)$. The area surveyed encompassed the coastal shelf $(<50 \mathrm{~m})$ north of the Aleutian Islands, the middle shelf $(50-100 \mathrm{~m})$ and outer shelf (100-180 m), slope (180-2000 m) and, in 1999 , limited basin $(>2000 \mathrm{~m}$ ) regions. The amount of survey effort $(\mathrm{km})$ is summarized by ecological domain (see Tables $2 \& 3$ ). Surveys were conducted in passing mode, while the ship transited between trawling stations, using closing mode only for sightings of very rare species (e.g. Tynan et al. 2001). From the flying bridge of the NOAA RV 'Miller Freeman', 2 observers simultaneously censused to the horizon with Fujinon $25 \times$ 150 binoculars equipped with compass and reticles. A third observer focused on the trackline, aided with $7 \times$ 50 hand-held binoculars. The eye height for observers

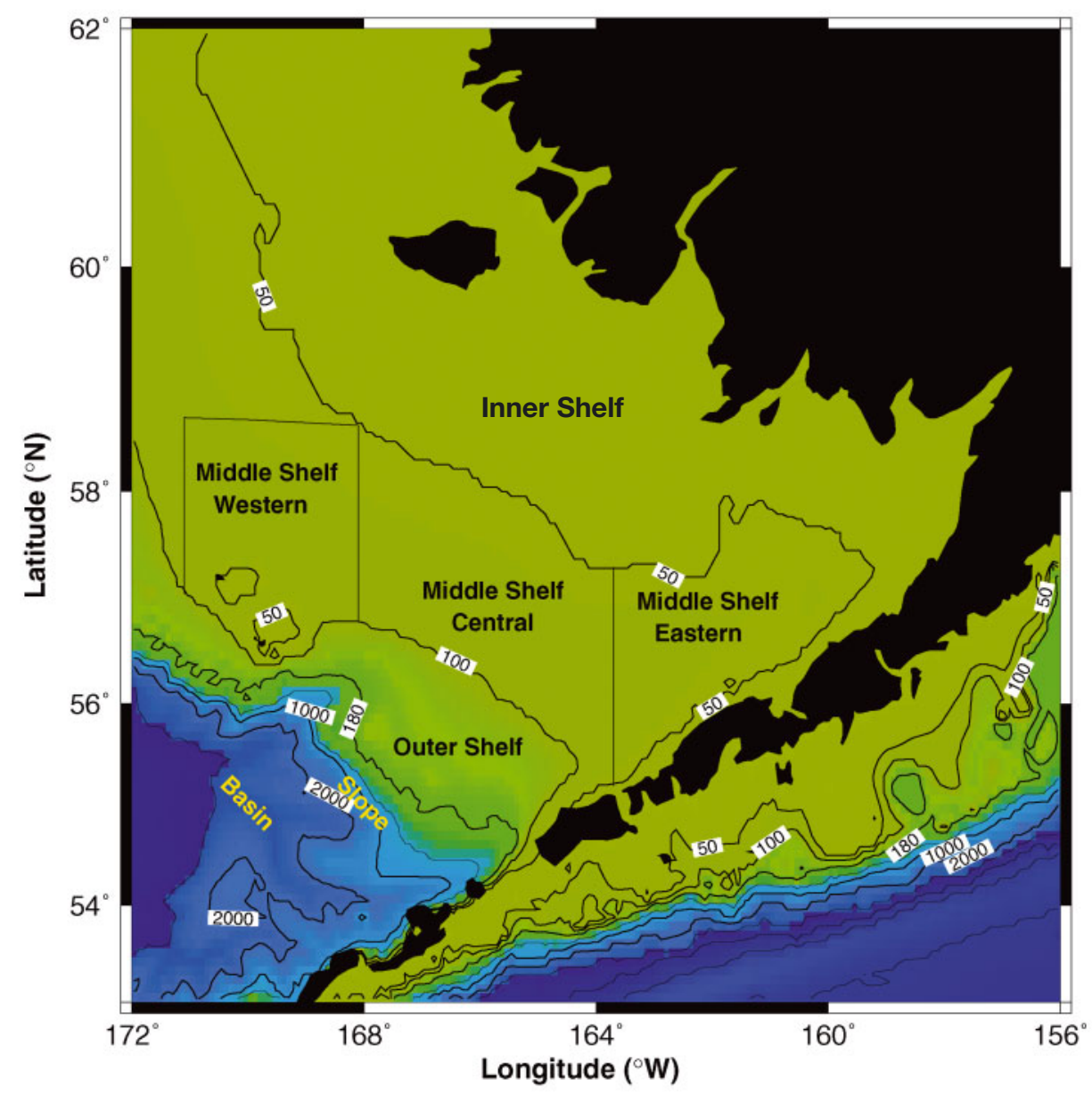

Fig. 1. Shelf domains of the SE Bering Sea used in stratified abundance estimates of cetaceans. For analyses, the middle shelf is divided into western $\left(168.1\right.$ to $\left.171.1^{\circ} \mathrm{W}\right)$, central $\left(163.7\right.$ to $\left.168.1^{\circ} \mathrm{W}\right)$ and eastern (160.3 to $\left.163.7^{\circ} \mathrm{W}\right)$ strata 
with the $25 \times 150$ binoculars was $12.4 \mathrm{~m}$ above sea level in 1997 and $12.1 \mathrm{~m}$ in 1999. The theoretical probability of sighting an animal on the trackline, $g_{0}$, was assumed to be 1.0 for all species. Cetacean orientation was not recorded during the sightings, and therefore estimated densities were uncorrected for any responsive movement of cetaceans to the ship (e.g. Palka \& Hammond 2001). All sightings were recorded on a laptop computer linked to the ship's GPS.

Cetacean abundances were stratified by cross-shelf domains of the SEBS, as defined by bathymetry (Fig. 1). For purposes of comparative density, abundance, and consumption estimation, the middle shelf was further stratified into eastern (160.3 to $\left.163.7^{\circ} \mathrm{W}\right)$, central (163.7 to $168.1^{\circ} \mathrm{W}$ ) and western ( 168.1 to $\left.171.1^{\circ} \mathrm{W}\right)$ strata for the SE shelf (Fig. 1). These middle-shelf ecological strata mirror 3 zones of significant physical along-shelf variability (Stabeno et al. 2002). Only sightings obtained while using 25-power binoculars ('on-effort', Fig. 2) in Beaufort 0-5 conditions were used in the abundance and density determinations. Cetacean densities were computed from the 1997 and 1999 sightings data with program DISTANCE (Laake et al. 1994). Program DISTANCE evaluates several models of detection probability as a function of the perpendicular distance of the sightings from the track-line. Selection of the model with the best fit was based on Akaike's Information Criterion (AIC) (Buckland et al. 2001): half-normal; hazard rate; and uniform models. Estimators were chosen based on the minimum AIC.

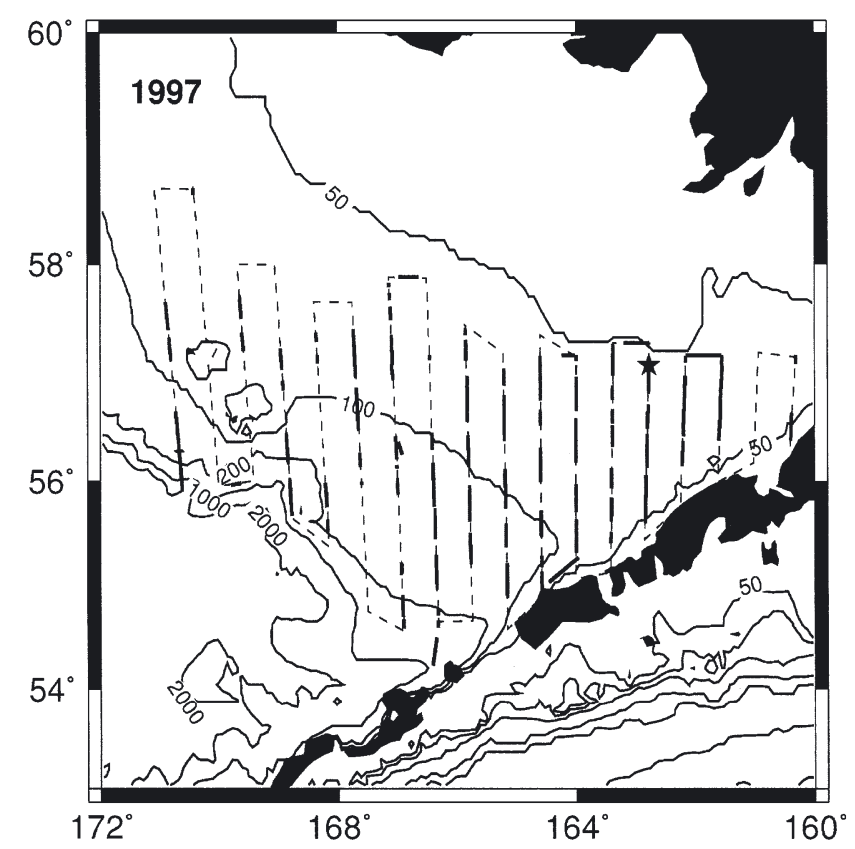

The best model fits for fin whale, humpback whale, Dall's porpoise, and harbor porpoise were obtained using the uniform/cosine, hazard rate, uniform/cosine, and uniform/cosine models, respectively. Using a filter on the 1997 Dall's porpoise data to truncate all sightings beyond $3.5 \mathrm{~km}$ improved the fit. The model fit for harbor porpoise data was improved by truncating the sightings at $2.5 \mathrm{~km}$. The model fit for the 1999 Dall's porpoise data was not significantly improved by truncation. For all other species (Table 1), the number of sightings was too low to provide reasonable stratified abundance estimates and, therefore, meaningful estimates of consumption, i.e. for minke whales Balaenoptera acutorostrata, sei whales $B$. borealis, and North Pacific right whales in both years, and for humpback whales and harbor porpoises in 1999.

Estimates of prey consumption by fin and humpback whales were based on published stomach content mass and estimates of daily consumption rates. For fin whales, the stomach content mass varies both geographically and with prey type, ranging as follows: $560 \mathrm{~kg}$ of euphausiids in $8 \mathrm{~h}$ off Nova Scotia (Brodie et al. 1978); $700 \mathrm{~kg}$ of euphausiids 4 times daily in the Antarctic (Zenkovich 1970); $759 \mathrm{~kg}$ of fish in a 57' (17.4 m) fin whale from the Bering Sea (Nemoto 1959). The latter may even be a slight underestimate, as the average lengths for male and female fin whales north of Unalaska Island, from the center of the fin whaling ground, 1954 to 1960, were 18.1 and $18.5 \mathrm{~m}$, respectively (Nasu 1974). Estimates of daily food consump-

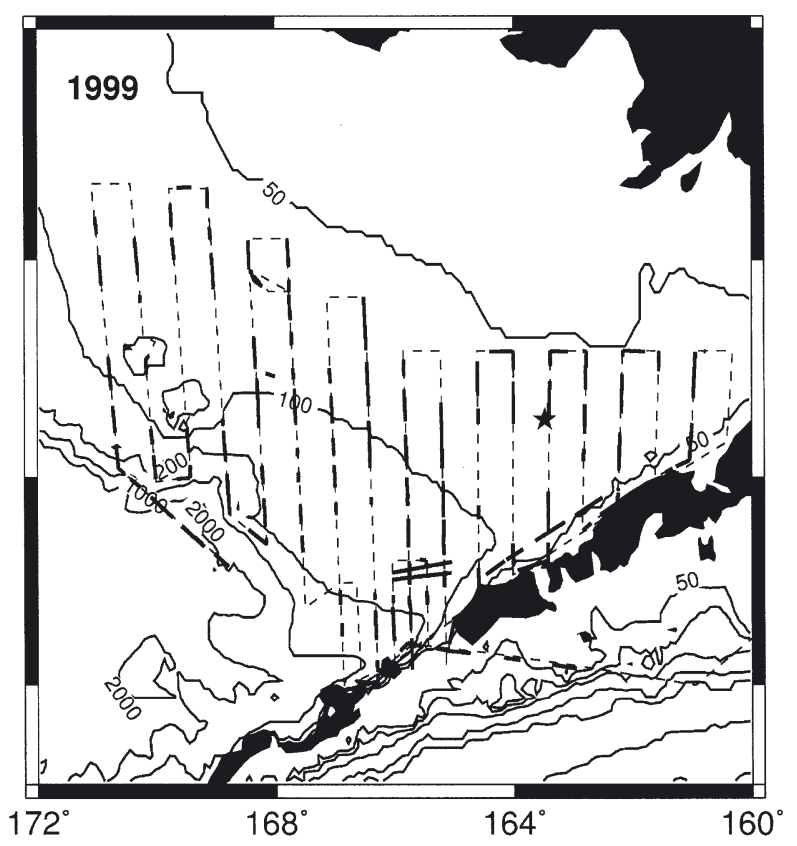

Fig. 2. Cruise track (dashed line) for continuous oceanographic sampling, CTD stations ( $\star$ ), and cetacean survey effort using 2 pairs of $25 \times 150$ binoculars (dark, solid line segments) in the SE Bering Sea from July 17 to August 5, 1997 and June 7 to July 1, 1999. Depth contour lines in meters 
Table 1. Summary of on-effort cetacean sightings for July 1997 and June 1999 surveys, with percent species composition of sightings for large whales

\begin{tabular}{|c|c|c|c|c|c|c|}
\hline \multirow[t]{2}{*}{ Species } & \multirow{2}{*}{ Sightings (N) } & \multirow{2}{*}{$\begin{array}{l}-1997 \\
\text { Animals }(\mathrm{N})\end{array}$} & \multirow{2}{*}{$\overline{\% \text { Total }}$} & \multirow[b]{2}{*}{ Sightings (N) } & \multirow{2}{*}{$\begin{array}{l}-1999- \\
\text { Animals (N) }\end{array}$} & \multirow{2}{*}{$\overline{\% \text { Total }}$} \\
\hline & & & & & & \\
\hline Fin whale & 21 & 29 & 32 & 64 & 177 & 89 \\
\hline Humpback whale & 33 & 45 & 50 & 6 & 11 & 6 \\
\hline Minke whale & 8 & 8 & 9 & 8 & 9 & 5 \\
\hline North Pacific right whale & 2 & 6 & 7 & 1 & 1 & 0.1 \\
\hline Sei whale & 2 & 2 & 2 & 0 & & \\
\hline Dall's porpoise & 84 & 299 & & 138 & 473 & \\
\hline Harbor porpoise & 110 & 153 & & 7 & 8 & \\
\hline Killer whale & 9 & 250 & & 9 & 54 & \\
\hline Pacific white-sided dolphin & 1 & 90 & & 1 & 125 & \\
\hline Berardius bairdii & 1 (dead) & 1 & & 0 & & \\
\hline
\end{tabular}

tion rates are even more uncertain. For the North Pacific, Kawamura (1971) suggested that fin whales fed twice daily at intervals of 10 to $15 \mathrm{~h}$. An 18-19 m fin whale in the North Pacific was claimed to consume 1000-1500 kg d ${ }^{-1}$ (Klumov 1961). Lockyer (1981) estimated that an adult fin whale requires a daily intake of 2000-2500 kg d ${ }^{-1}$ in order to meet metabolic demands. From this range of estimates $(500-700 \mathrm{~kg}$ prey per feeding session), assuming that baleen whales fill their stomachs 2 to 4 times daily according to species and local food availability (Kawamura 1971, Brown \& Lockyer 1984), fin whales could consume 1000-2800 $\mathrm{kg} \mathrm{d}^{-1}$. Based on the presence of fin whales on the middle shelf during surveys conducted in July-August 1997 and June 1999, a 4-mo summer foraging season from June through September is assumed. During summer, the eastern Bering Sea shelf is ice-free (Stabeno et al. 2002) and therefore available to foraging whales. Further, it has been estimated that most fin whales probably remain on Antarctic feeding grounds for at least 4 mo (Lockyer 1981). Over $4 \mathrm{mo}$, a fin whale would therefore consume 120000-336000 kg prey (equivalent to 120-336 metric tons (mt) of prey). These assumptions provide the basis for the range of consumption estimates computed for fin whales from the point estimates of abundance for each strata of the SEBS (Tables 2 \& 3).

It is estimated that baleen whales consume 3 to $4 \%$ of their body weight per day during the feeding season (Klumov 1963, Sergeant 1969). For a 30 US ton humpback whale, this is the equivalent of 815-1087 $\mathrm{kg} \mathrm{d}^{-1}$. In the Antarctic, a humpback whale consumes approximately $500 \mathrm{~kg}$ prey during a feeding session and $2200 \mathrm{~kg}$ of krill daily (Zenkovich 1969). Over a 4 mo summer feeding season, a humpback whale would therefore consume on the order of 97 800-264 $000 \mathrm{~kg}$ prey (equivalent to 98-264 $\mathrm{mt}$ of prey). This range of consumption estimates forms the basis for prey consumption by humpback whales (Table 2).
Estimates of prey consumption by Dall's porpoises and harbor porpoises were also based on values published in the literature. From captive studies, Dall's porpoise appear to require $15 \mathrm{~kg}$ of prey daily to maintain body weight (Ridgway 1966). Harbor porpoises of various body sizes consume $750-3250 \mathrm{~g} \mathrm{~d}^{-1}$ of fishes, such as herring, while in captivity (Kastelein et al. 1997). Over a 4 mo feeding season in the Bering Sea, a Dall's porpoise could therefore consume approximately $1800 \mathrm{~kg}$ prey (equivalent to $1.8 \mathrm{mt}$ ), while a harbor porpoise could consume between 90 and $390 \mathrm{~kg}$ of prey (equivalent to $0.09-0.39 \mathrm{mt}$ ). These values form the basis for the estimates of prey consumption by Dall's porpoises and harbor porpoises (Tables $2 \& 3$ ).

To estimate the amounts of carbon ingested by whales and either respired to the atmosphere or egested, an average of $10 \% \mathrm{C} \mathrm{g}^{-1}$ prey was assumed (van Franeker et al. 1997). In addition, following Huntley et al. (1991), it was assumed that approximately $75 \%$ of the carbon ingested by whales is ultimately respired as $\mathrm{CO}_{2}$ over the course of migrations and winter. This percentage is similar to an estimated assimilation efficiency of 77 to $79 \%$ for young adult female and male fin whales, respectively (Lockyer 1981). The remaining $25 \%$ of ingested carbon is assumed to be lost through egestion (i.e. excretion). These assumptions form the basis of the estimates of carbon either respired or egested by fin whales and humpback whales (Tables $2 \& 3$ ). The estimates for carbon cycling rely on the stratified abundance estimates, which do not reflect age or sex of the whales. Given that both these factors affect metabolism and energy pathways, the initial estimates of carbon transfer by fin and humpback whales could be further refined by incorporating age-dependent metabolism and energy pathways in the model. Although the presence of calves was recorded in the sightings data, specific data on age and sex structure in these summer populations are presently unavailable. 
Table 2. Balaenoptera physalus, Megaptera novaeangliae, Phocoenoides dalli and Phocoena phocoena. Summary of 1997 line-transect survey parameters of density ( $\mathrm{D}$, individuals $\mathrm{km}^{-2}$; highest in bold), abundance ( $\mathrm{N}$, highest in bold), ingestion (I, metric tons prey consumed over 4 mo), respiration ( $R$, metric tons carbon respired to the atmosphere), and egestion (Eg, metric tons carbon egested) in the SE Bering Sea. (160.32 to $171.08^{\circ} \mathrm{W}$, Fig. 1): inner shelf north of the Alaska Peninsula (<50 m depth); middle shelf (50-100 m); outer shelf (100-180 m); slope 180-2000 m; and basin $(>2000 \mathrm{~m})$. The middle shelf was further stratified into eastern $\left(160.3\right.$ to $\left.163.7^{\circ} \mathrm{W}\right)$, central $\left(163.7\right.$ to $\left.168.1^{\circ} \mathrm{W}\right)$ and western $(168.1$ to $171.1^{\circ} \mathrm{W}$ ) middle shelf strata (Fig. 1). Parameters for each stratum include: effort ( $\mathrm{E}, \mathrm{km}$ surveyed), number of sightings included (S), effective strip width $(E S W, \mathrm{~km})$, encounter rate (ER, sightings per km surveyed), and mean group size (E(S), number of cetaceans per group). Abundance $(\mathrm{N})=($ Area $\times \mathrm{E}(\mathrm{S}) \times \mathrm{S}) /(2 \times \mathrm{ESW} \times \mathrm{E})$. Percent coefficient of variation $(\mathrm{CV})$ in parentheses

\begin{tabular}{|c|c|c|c|c|c|c|c|c|c|c|}
\hline & $\begin{array}{c}\mathrm{E} \\
(\mathrm{km})\end{array}$ & $\mathrm{S}$ & $\begin{array}{c}\mathrm{ER} \\
\left(\mathrm{n} \mathrm{km}^{-1}\right)\end{array}$ & $\mathrm{E}(\mathrm{S})$ & $\begin{array}{c}\mathrm{D} \\
\text { (ind. } \mathrm{km}^{-2} \text { ) }\end{array}$ & $\begin{array}{l}\text { Area } \\
\left(\mathrm{km}^{2}\right)\end{array}$ & $\mathrm{N}$ & $\begin{array}{c}\mathrm{I} \\
(\mathrm{mt})\end{array}$ & $\begin{array}{c}\mathrm{R} \\
(\mathrm{mt})\end{array}$ & $\begin{array}{l}\mathrm{Eg} \\
(\mathrm{mt})\end{array}$ \\
\hline \multicolumn{11}{|c|}{ Fin whale Balaenoptera physalus $(\mathrm{ESW}=5.39 \mathrm{~km} ; \mathrm{CV}=14.2 \%)$} \\
\hline Inner shelf; Aleutians & 26.2 & 0 & 0.0 & & 0 & 9207 & 0 & & & \\
\hline Middle shelf, eastern & 172.5 & 1 & 0.0058 (63.5) & 1.0 & $0.000538(65.0)$ & 30586 & $16(65.0)$ & $1920-5376$ & $144-403$ & $48-134$ \\
\hline Middle shelf, central & 170.7 & 11 & $0.0645(56.6)$ & $1.55(18.2)$ & $0.00924(61.1)$ & 55466 & $513(61.1)$ & $61560-172368$ & $4617-12928$ & $1539-4309$ \\
\hline Middle shelf, western & 50.8 & 1 & $0.0197(95.6)$ & 1.0 & $0.00183(96.7)$ & 35822 & 65 (96.7) & $7800-21840$ & $585-1638$ & $195-546$ \\
\hline Outer shelf & 224.7 & 9 & $0.0401(46.6)$ & 1.24 & $0.00459(50.3)$ & 43521 & $200(50.3)$ & $24000-67200$ & $1800-5040$ & $600-1680$ \\
\hline Slope & 134.0 & 0 & 0.0 & & 0 & 23740 & 0 & & & \\
\hline Total & 778.9 & 22 & - & - & $0.00400(43.4)$ & 198342 & $794(43.3)$ & $95280-266784$ & $7146-20009$ & $2382-6669$ \\
\hline \multicolumn{11}{|c|}{ Humpback whale Megaptera novaeangliae (ESW $=3.01 \mathrm{~km} ; \mathrm{CV}=25.1 \%$ ) } \\
\hline Inner shelf; Aleutians & 26.2 & 1 & $0.0382(100.0)$ & 1.0 & $0.00635(103.0)$ & 9207 & $58(103.1)$ & $5183-15312$ & $389-1148$ & $130-383$ \\
\hline Middle shelf, eastern & 172.5 & 6 & $0.0348(70.6)$ & $1.33(25.0)$ & $0.00770(79.0)$ & 30586 & $235(79.0)$ & $22983-62040$ & $1724-4653$ & $575-1551$ \\
\hline Middle shelf, central & 170.7 & 23 & $0.135(59.0)$ & $1.05(8.0)$ & $0.0236(64.6)$ & 55466 & $1308(64.6)$ & $127922-345312$ & $9594-25898$ & 3198-8632 \\
\hline Middle shelf, western & 50.8 & 0 & 0.0 & & 0.0 & 35822 & 0 & & & \\
\hline Outer shelf & 224.7 & 3 & $0.0134(88.0)$ & $1.33(25.0)$ & $0.00295(94.8)$ & 43521 & $129(94.8)$ & $12616-34056$ & $946-2554$ & $315-851$ \\
\hline Slope & 134.0 & 0 & 0.0 & & 0.0 & 23740 & 0 & & & \\
\hline Total & 778.9 & 33 & - & - & $0.00872(53.1)$ & 198342 & $1730(53.1)$ & $169194-456720$ & $12690-34254$ & $4230-11418$ \\
\hline \multicolumn{11}{|c|}{ Dall's porpoise Phocoenoides dalli $(\mathrm{ESW}=1.05 \mathrm{~km} ; \mathrm{CV}=9.49 \%$ ) } \\
\hline Inner shelf; Aleutians & 26.2 & 0 & 0 & & & 9207 & & & & \\
\hline Middle shelf, eastern & 172.5 & 7 & $0.0406(58.2)$ & $3.29(25.5)$ & $0.0633(64.2)$ & 30586 & $1936(64.2)$ & 3485 & & \\
\hline Middle shelf, central & 170.7 & 14 & $0.0820(32.7)$ & $4.36(15.9)$ & $0.170(37.6)$ & 55466 & 9409 (37.6) & 16936 & & \\
\hline Middle shelf, western & 50.8 & 0 & 0 & & & 35822 & & & & \\
\hline Outer shelf & 224.7 & 34 & $0.151(57.6)$ & $2.97(12.8)$ & $0.213(59.8)$ & 43521 & 9283 (59.8) & 16709 & & \\
\hline Slope & 134.0 & 19 & $0.142(43.8)$ & $4.16(13.0)$ & $0.280(46.6)$ & 23740 & $6640(46.6)$ & 11952 & & \\
\hline Total & 778.9 & 74 & - & - & $0.137(28.2)$ & 198342 & $27268(28.2)$ & 49082 & & \\
\hline \multicolumn{11}{|c|}{ Harbor porpoise Phocoena phocoena $(\mathrm{ESW}=1.09 \mathrm{~km} ; \mathrm{CV}=8.0 \%)$} \\
\hline Inner shelf; Aleutians & 26.2 & 0 & 0.0 & & & 9207 & & & & \\
\hline Middle shelf, eastern & 172.5 & 48 & $0.278(30.2)$ & $1.40(6.5)$ & $0.180(32.0)$ & 30586 & $5508(32.0)$ & $496-2148$ & & \\
\hline Middle shelf, central & 170.7 & 58 & $0.340(33.8)$ & $1.31(6.6)$ & $0.205(35.4)$ & 55466 & $11377(34.4)$ & $1024-4437$ & & \\
\hline Middle shelf, western & 50.8 & 0 & 0.0 & & & 35822 & & & & \\
\hline Outer shelf & 224.7 & 0 & 0.0 & & & 43521 & & & & \\
\hline Slope & 134.0 & 0 & 0.0 & & & 23740 & & & & \\
\hline Total & 778.9 & 106 & - & - & $0.0851(26.6)$ & 198342 & $16885(26.6)$ & $1520-6585$ & & \\
\hline
\end{tabular}

Near-surface $(\sim 5 \mathrm{~m})$ along-track sea surface temperature (SST) and salinity were sampled through the ship's continuous flow-through seawater system. Values were recorded automatically every minute. The data were passed through a nearest-neighbor gridding algorithm with $10 \mathrm{~km}$ quadrant search radius and grid spacing of 10' latitude and 5' longitude (Fig. 3). Empty grid cells near the coast (i.e. Aleutians) and beyond the boundaries of the survey area were flagged. CTD profiles provided the description of the vertical temperature and salinity structure on the middle shelf during 21 July 1997 (GMT) and 15 June 1999 (GMT); the depths at the CTD stations were 58 and $80 \mathrm{~m}$, respectively (Fig. 2).
Chlorophyll a samples $(\mathrm{n}=131$, Fig. 4$)$ were collected from the near-surface $(5.5 \mathrm{~m}$ depth) via the along-track flow-through system on the ship. A $289 \mathrm{ml}$ Nalgene bottle was used to collect seawater samples from the flow-through system. The Nalgene bottle was rinsed with freshwater after each sample collection. Water samples were filtered by vacuum pump ( $175 \mathrm{~mm} \mathrm{Hg})$ through Whatman GF/F $24 \mathrm{~mm}$ glass microfibre filters. Filters were folded in four using forceps, were placed in microcentrifuge tubes, and were frozen at $-80^{\circ} \mathrm{C}$. In the laboratory, frozen filters were cut in half; one-half was reserved for SEM analysis and the other half for chlorophyll extraction. To allow for some warming in order to unfold and cut the filters, 
Table 3. Balaenoptera physalus and Phocoenoides dalli. Summary of the 1999 line-transect survey parameters by ecological strata, as defined in Table 2, for density ( $\mathrm{D}$, individuals $\mathrm{km}^{-2}$; highest in bold), abundance (N, highest in bold), ingestion (I, metric tons (mt) prey consumed over $4 \mathrm{mo}$ ), respiration ( $\mathrm{R}$, metric tons (mt) carbon respired to the atmosphere), and egestion (Eg, metric tons (mt) carbon egested) in the SE Bering Sea (160.32 to $171.08^{\circ} \mathrm{W}$; see Fig. 1 for areas). Parameters for each stratum include: effort (E, km surveyed), number of sightings included (S), effective strip width (ESW, km), encounter rate (ER, sightings per $\mathrm{km}$ surveyed), and mean group size (E(S), number of cetaceans per group).

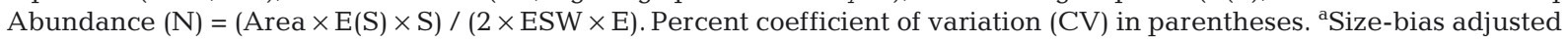

\begin{tabular}{|c|c|c|c|c|c|c|c|c|c|c|}
\hline & $\begin{array}{c}E \\
(\mathrm{~km})\end{array}$ & $\mathrm{S}$ & $\begin{array}{c}\mathrm{ER} \\
\left(\mathrm{n} \mathrm{km}^{-1}\right)\end{array}$ & $\mathrm{E}(\mathrm{S})$ & $\begin{array}{c}\mathrm{D} \\
\text { (ind. } \mathrm{km}^{-2} \text { ) }\end{array}$ & $\begin{array}{l}\text { Area } \\
\left(\mathrm{km}^{2}\right)\end{array}$ & $\mathrm{N}$ & $\begin{array}{c}\mathrm{I} \\
(\mathrm{mt})\end{array}$ & $\begin{array}{c}\mathrm{R} \\
(\mathrm{mt})\end{array}$ & $\begin{array}{c}\mathrm{Eg} \\
(\mathrm{mt})\end{array}$ \\
\hline \multicolumn{11}{|c|}{ Fin whale Balaenoptera physalus (ESW $=5.57 \mathrm{~km} ; \mathrm{CV}=11.3 \%$ ) } \\
\hline Inner shelf; Aleutians & 182.5 & 0 & 0 & & 0 & 9207 & 0 & & & \\
\hline Middle shelf, eastern & 424.9 & 1 & $0.00235(78.0)$ & 1.0 & $0.000211(78.8)$ & 30586 & $6(78.8)$ & $720-2016$ & $54-151$ & $18-50$ \\
\hline Middle shelf, central & 631.5 & 46 & $0.0728(50.4)$ & $2.59(16.8)$ & $0.0169(54.3)$ & 55466 & $938(54.3)$ & $112560-315168$ & $8442-23638$ & 2814-7879 \\
\hline Middle shelf, western & 379.8 & 0 & 0 & & 0 & 35822 & 0 & & & \\
\hline Outer shelf & 668.0 & 1 & $0.00159(121.0)$ & 3.0 & $0.000403(121.5)$ & 43521 & $18(121.5)$ & $2160-6048$ & $162-454$ & $54-151$ \\
\hline Slope & 430.1 & 15 & $0.0349(58.9)$ & $2.48^{\mathrm{a}}(22.7)$ & $0.00777(64.1)$ & 23740 & $185(64.1)$ & $22200-62160$ & $1665-4662$ & $555-1554$ \\
\hline Basin-edge & 23.2 & 1 & $0.0431(100.0)$ & 1.0 & $0.00387(100.6)$ & 9496 & $37(100.6)$ & $4440-12432$ & $333-932$ & $111-311$ \\
\hline Total & 2740.0 & 64 & - & - & $0.00569(44.8)$ & 207833 & $1184(44.8)$ & $142080-397824$ & $10656-29837$ & $3552-9946$ \\
\hline \multicolumn{11}{|c|}{ Dall's porpoise Phocoenoides dalli $(\mathrm{ESW}=0.95 \mathrm{~km} ; \mathrm{CV}=13.5 \%)$} \\
\hline Inner shelf; Aleutians & 182.5 & 9 & $0.0493(86.8)$ & $2.0(26.4)$ & $0.0519(91.7)$ & 9207 & $478(91.7)$ & 860 & & \\
\hline Middle shelf, eastern & 424.9 & 4 & $0.00941(90.7)$ & $2.5(11.6)$ & $0.0124(92.4)$ & 30586 & $379(92.4)$ & 682 & & \\
\hline Middle shelf, central & 631.9 & 18 & $0.0285(56.0)$ & $3.33(14.8)$ & $0.0500(59.5)$ & 55466 & $2776(59.5)$ & 4997 & & \\
\hline Middle shelf, western & 379.8 & 2 & $0.00527(79.3)$ & $1.50(33.3)$ & $0.00416(87.1)$ & 35822 & $149(87.1)$ & 268 & & \\
\hline Outer shelf & 668.0 & 24 & $0.0359(51.3)$ & $3.38(9.4)$ & 0.0639 (53.9) & 43521 & $2780(53.9)$ & 5004 & & \\
\hline Slope & 430.1 & 53 & $0.123(29.4)$ & $3.96(8.5)$ & $0.257(33.4)$ & 23740 & $6105(33.4)$ & 10989 & & \\
\hline Basin-edge & 23.2 & 26 & $1.122(19.6)$ & $3.50(9.4)$ & $2.068(25.6)$ & 9496 & $19636(25.6)$ & 35345 & & \\
\hline Total & 2740.0 & 136 & - & - & $0.155(21.0)$ & 207833 & 32303 (21.0) & 58145 & & \\
\hline
\end{tabular}

10 vials were removed from the $-80^{\circ} \mathrm{C}$ freezer at a time. Chlorophyll was extracted from half-filters in darkness over $24 \mathrm{~h}$ at $-80^{\circ} \mathrm{C}$ using $10 \mathrm{ml}$ of acetone. Samples were thawed for 30 min prior to analysis on a Turner Designs 10-AU fluorometer. The data were passed through a nearest-neighbor gridding algorithm with $5 \mathrm{~km}$ quadrant search radius and grid spacing of 10' latitude and 10' longitude (Fig. 3). Empty grid cells near the coast (i.e. Aleutians) and beyond the boundaries of the survey area were flagged.

\section{RESULTS}

\section{Ocean conditions}

Conditions during summer 1997 were dominated by atmospheric forcing linked to a powerful El Niño. SSTs were 3 to $4^{\circ} \mathrm{C}$ above average by June. SST on the eastern and central strata of the SEBS middle shelf was $>11^{\circ} \mathrm{C}$ (Fig. 3) during July, when winds were low, seas were calm, and from July 19 to 24 surface conditions ranged from Beaufort 0 to 3. During July, the water column of the middle shelf consisted of a well-stratified 2layer structure. A warm $\left(10\right.$ to $\left.12^{\circ} \mathrm{C}\right)$ mixed surface layer extended to a depth of $\sim 15 \mathrm{~m}$, overlying a strong thermocline of $>6^{\circ} \mathrm{C}$ and a bottom layer of $\sim 3^{\circ} \mathrm{C}$. There was no evidence of a cold pool of $<2^{\circ} \mathrm{C}$ on the middle shelf. It was in these conditions that the first-recorded extensive coccolithophore Emiliania huxleyi bloom occupied the SEBS middle shelf (Fig. 4). Records of our passage in and out of the aqua-colored bloom provided the first synoptic measure of the spatial extent of this developing feature (Fig. 4). During July 1997, the bloom was restricted to the middle shelf (Fig. 4) and was elongated in the east-west dimension: $380 \mathrm{~km}$ wide $(\mathrm{E}-\mathrm{W})$ by 10 to $40 \mathrm{~km}(\mathrm{~N}-\mathrm{S})$. We first observed the eastern edge of the bloom on 19 July 1997, in $73 \mathrm{~m}$ and $\mathrm{SST}=11.95^{\circ} \mathrm{C}$, along a northerly transect at $161^{\circ} 34.6^{\prime}$ W. On July 29 , the western interleaving-edge of the bloom was encountered along $167^{\circ} 41.63^{\prime} \mathrm{W}$ $\left(88 \mathrm{~m}, \mathrm{SST}=11.0^{\circ} \mathrm{C}\right.$, surface salinity $\left.=31.724\right)$. These observations of the bloom preceded the launch of NASA's Sea-viewing Wide Field-of-View Sensor (SeaWiFS) ocean color scanner, which provided excellent imagery of this feature later in September 1997. During July, the bloom occurred in SSTs ranging from 11 to $12^{\circ} \mathrm{C}$, with the warmest water in the east. Near-surface $(\sim 5.5 \mathrm{~m})$ concentrations of chlorophyll a in the coccolithophore bloom were on the order of 1 to $2 \mu \mathrm{g} \mathrm{l}^{-1}$ (Fig. 4) and were among the higher values for the middle and outer shelves. The shelf-edge and slope however had the highest concentration of chlorophyll a (2 to $33 \mu \mathrm{g} \mathrm{l^{-1 }}$, Fig. 4).

In contrast to 1997, SSTs on the middle shelf during June 1999 were 4 to $6^{\circ} \mathrm{C}$ colder than July 1997 (Fig. 3). 

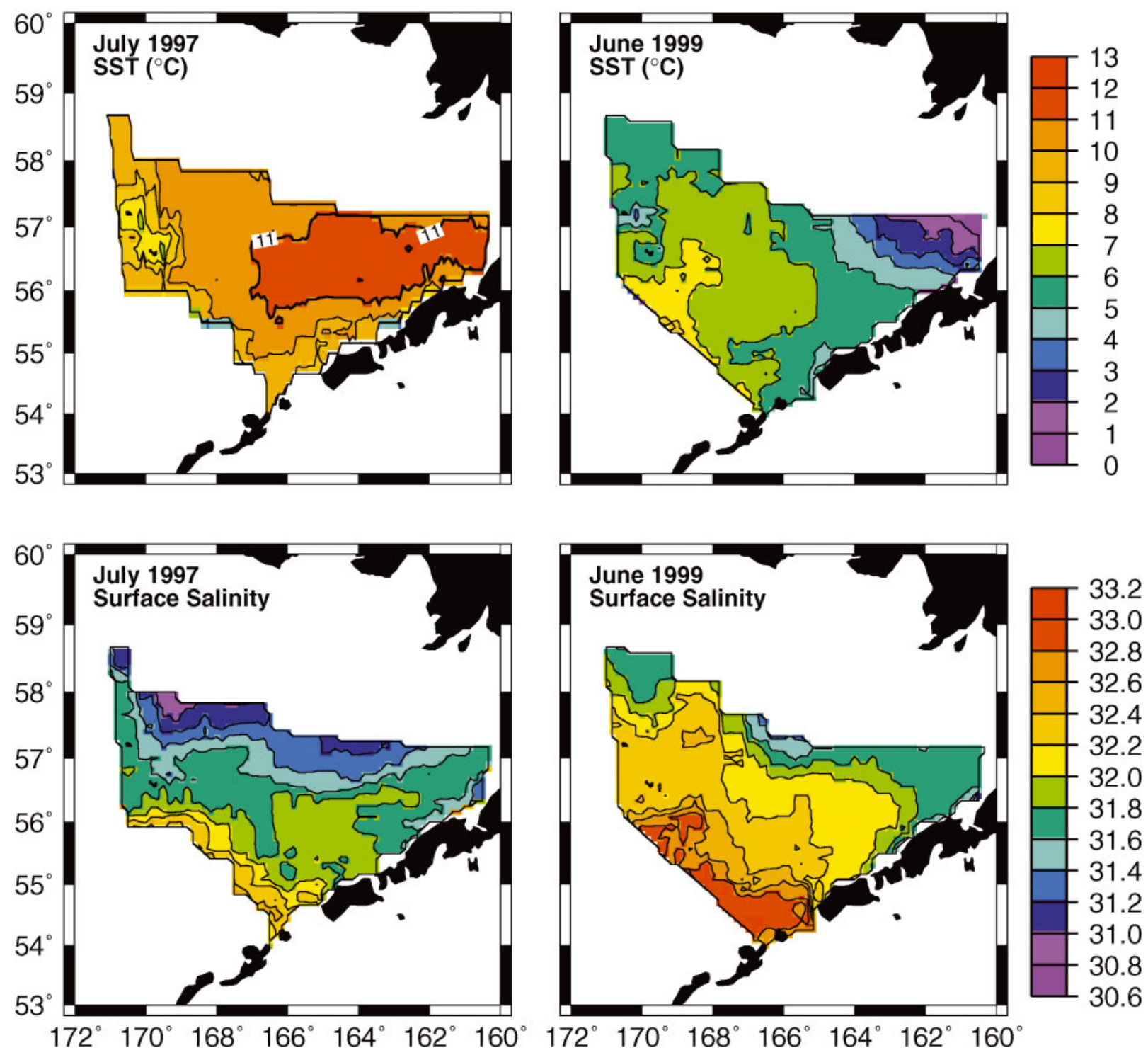

Fig. 3. Along-track sea surface ( 5.5 m) temperature (SST) and salinity during July 1997 and June 1999

In the lower layer $(>29 \mathrm{~m})$ of the middle-shelf water column, the water temperature was $<2{ }^{\circ} \mathrm{C}$, evidence of the cold pool. Although 1997 was a heavier ice year than 1999, the ice retreated earlier in 1997 (April) than in 1999 (May). Shelf surface salinities were lower in July 1997 than June 1999 by 0.3 to 0.4, as is expected during a heavier ice year (Fig. 3).

During June 1999, when the ice had only recently left the middle shelf, there was no aqua-colored surface evidence of the coccolithophore bloom in the survey region. There was however evidence of the bloom closer to Nunivak Island (from imagery provided by the SeaWiFS Project, NASA/Goddard Space Flight Center). By July and August the bloom was again visibly evident and was confirmed by microscopy (Olson \& Strom 2002).

\section{Distribution and abundance of large cetaceans}

On the middle shelf of the SEBS during July 1997, 5 species of baleen whale were present: humpback whale, fin whale, sei whale, minke whale, and the North Pacific right whale (Table 1, Fig. 5). The latter 3 species were rare in comparison to fin and humpback whales. During July 1997, humpback whales were the most numerically dominant large whale $(\mathrm{N}=1730$, $\mathrm{CV}=0.53)$, followed by fin whales $(\mathrm{N}=794, \mathrm{CV}=$ 0.43), in the SEBS east of $171^{\circ} \mathrm{W}$ (Table 2). Conversely, during June 1999, fin whales were the most common large whale ( $\mathrm{N}=1184, \mathrm{CV}=0.45$, Table 3 ) and humpback whales were relatively rare on the shelf. Mysticete whales were more numerous in the middle shelf (50 $\mathrm{m}<\mathrm{z}<100 \mathrm{~m})$ than in other shelf or slope regions 

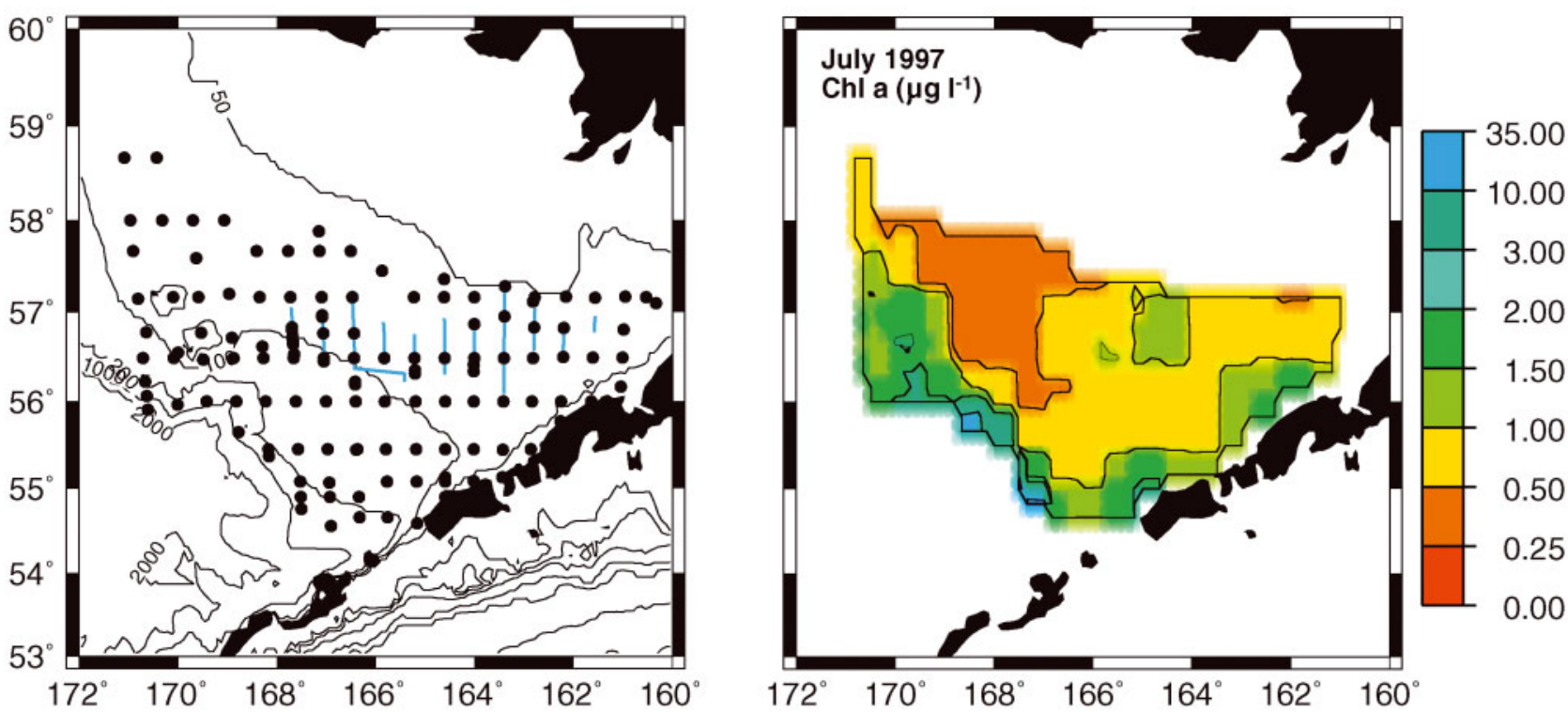

Fig. 4. Chlorophyll sampling stations (•), extent of a coccolithophore bloom of Emiliania huxleyi (blue lines) on the middle shelf, and surface $(\sim 5.5 \mathrm{~m})$ chlorophyll a concentration $\left(\mu \mathrm{g} \mathrm{l}^{-1}\right)$ of the SE Bering Sea, July 17 to August 5, 1997

of the SEBS during July 1997 and June 1999 (Figs. 5 \& 6, Tables 2 \& 3). Sei whales and right whales were found exclusively in the well stratified water column of the middle shelf, whereas minke whales were less restrictive in shelf domain.

The 'central' middle shelf of the SEBS (163.7 to $168.1^{\circ} \mathrm{W}$, Fig. 1) was the most important foraging ground for fin whales during both years, and for humpback whales during July 1997 (Figs. 5 \& 6, Tables 2
\& 3). The density and abundance for humpback and fin whales were highest on the central middle shelf during 1997: 0.0236 whales $\mathrm{km}^{-2}(\mathrm{~N}=1308, \mathrm{CV}=0.65)$, and 0.00924 whales $\mathrm{km}^{-2}(\mathrm{~N}=513, \mathrm{CV}=0.61)$, respectively (in bold in Table 2). The 'eastern' middle shelf (160.3 to $163.7^{\circ} \mathrm{W}$, Fig. 1) of the SEBS was the second most important habitat for humpback whales, followed by the outer shelf $(100 \mathrm{~m}<\mathrm{z}<180 \mathrm{~m})$. The 'western' middle shelf stratum of the SEBS (168.1 to $171.1^{\circ} \mathrm{W}$, Fig. 1),
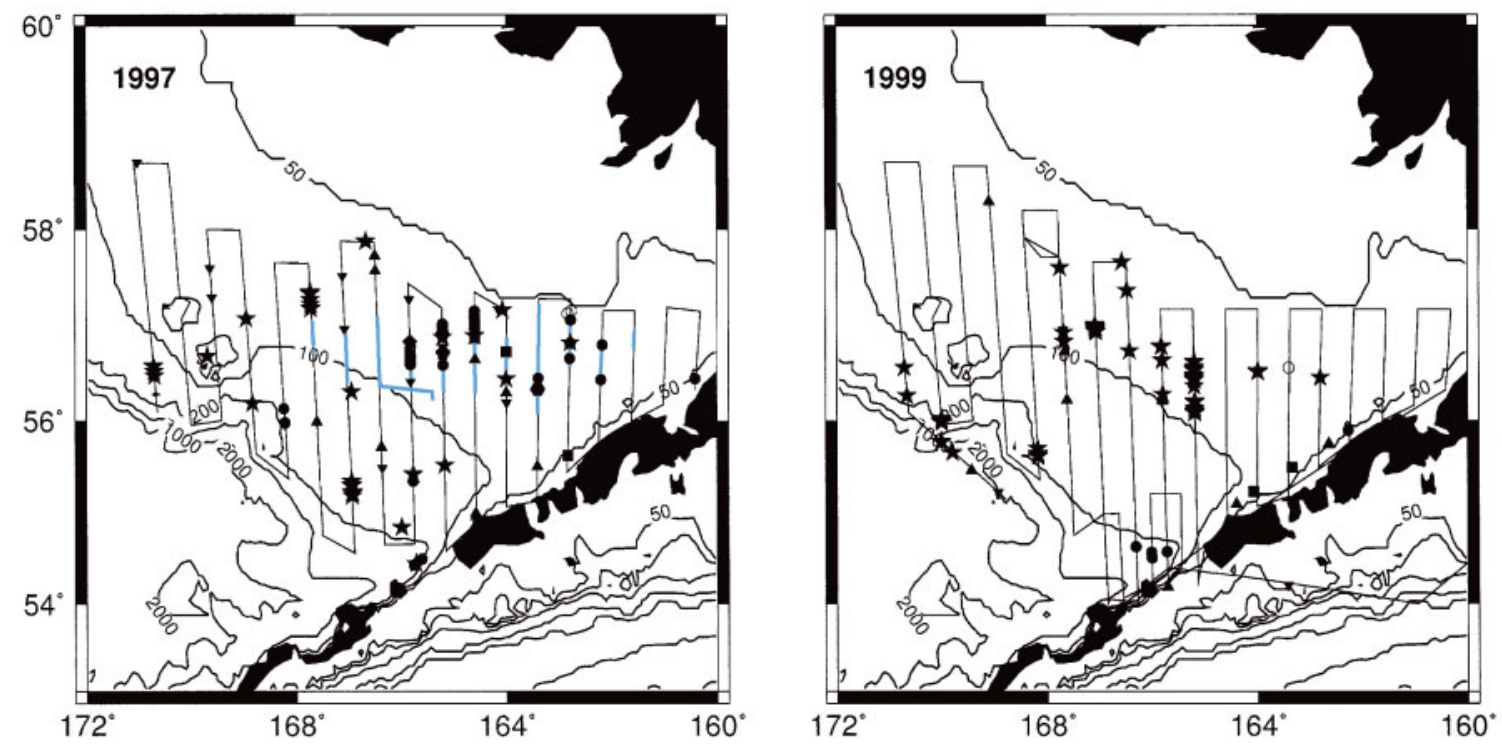

Fig. 5. Distribution of large whales in the SE Bering Sea from July 17 to August 5, 1997, in relation to a coccolithophore bloom (blue lines), and from June 11 to July 3, 1999. $\star$ : fin whale; $\bullet$ : humpback; o: right whale; $\mathbf{\Delta}$ : minke; $\bullet$ sei; $\bullet$ : fin or sei; - : Balaenoptera sp.; $\mathbf{v}$ : unidentified 

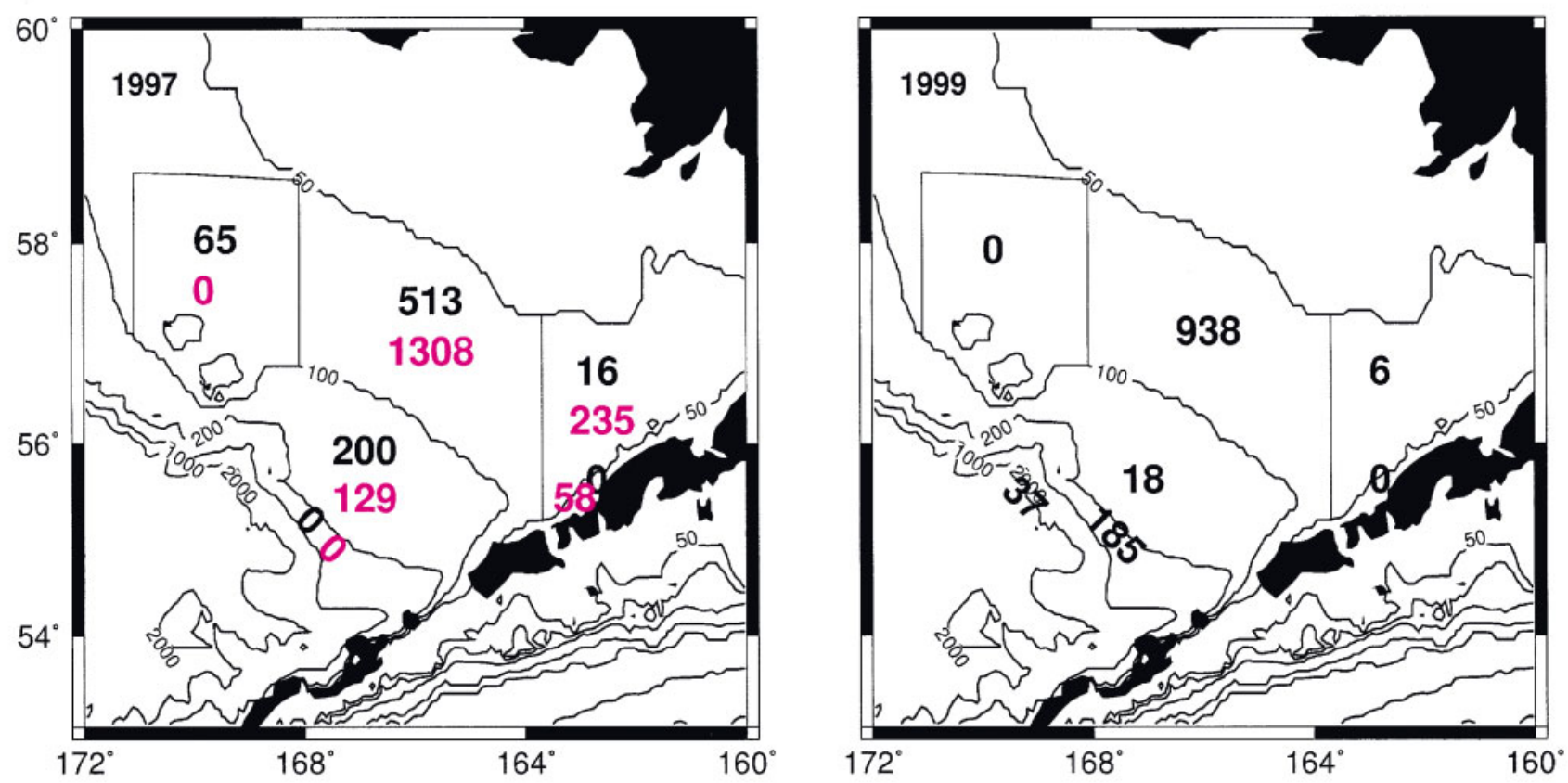

Fig. 6. Balaenoptera physalus and Megaptera novaeangliae. Abundance estimates of dominant whale species in the SE Bering Sea, stratified by shelf domain for fin whales (black) and humpback whales (red) from July 17 to August 5, 1997 and for fin whales from June 14 to July 3, 1999

north of and adjacent to the Pribilof Islands, apparently provided a far less favorable habitat for humpback and fin whales than did the 'central' middle shelf (Tables 2 \& 3, Fig. 6). The 1997 abundance estimates for the central middle shelf represent $76 \%$ of all humpback whales and $65 \%$ of all fin whales in the surveyed shelf and slope regions of the SEBS east of $171^{\circ} \mathrm{W}$. The abundance of humpback whales on the middle shelf in 1997 was an order of magnitude greater than that of the outer shelf and slope $(180 \mathrm{~m}<\mathrm{z}<2000 \mathrm{~m})$.

During June 1999, the highest density and abundance of fin whales again occurred in the central middle shelf stratum (0.0169 whales $\mathrm{km}^{-2}, \mathrm{~N}=938$, $\mathrm{CV}=0.54$ ) (Table 3, Figs. $5 \& 6$ ), representing $79 \%$ of all fin whales in the surveyed regions. The abundance of fin whales in the central middle shelf, just north of the Middle Front ( 100 $\mathrm{m}$ isobath) in water shallower than $100 \mathrm{~m}$, was 1-2 orders of magnitude greater than that of the outer shelf and slope (Fig. 6). Fin whales occurred in the central middle-shelf stratum in both years despite large differences in the physical forcing in the system. Of note in June 1999, large groups of fin whales (of up to 18 individuals), packed tightly together, were found on the central middle shelf $\left(\sim 57^{\circ} \mathrm{N}, 167.1^{\circ} \mathrm{W}\right)$. A few large groups of fin whales (of up to 13 individuals) were also found on the slope south of the Pribilof Islands $\left(\sim 56^{\circ} \mathrm{N}, 170.0^{\circ} \mathrm{W}\right)$. Such large tight groups were not observed during July 1997.
Fin whales returned to the middle shelf during summer in both 1997 and 1999 despite the strong difference in the atmosphere-ice dynamics and ocean response (Figs. 3, 4, 5 \& 6). Humpback whales, however, were far more numerous on the warm $\left(>11.0^{\circ} \mathrm{C}\right)$ middle shelf in July 1997 than in cooler conditions (SST $=4$ to $7^{\circ} \mathrm{C}$ ) of June 1999 (Figs. 3, 5 \& 6, Tables 1 \& 2). A cluster of humpback sightings occurred in June 1999 on the SE slope between the 180 and $1000 \mathrm{~m}$ isobaths, north of Akutan Island (Fig. 5), in SST $=5$ to $6^{\circ} \mathrm{C}$. The 1 mo difference in the timing of the 2 surveys may account for the paucity of humpbacks on the shelf in June 1999, when ice had only recently left the system. This species may have responded more strongly to the different oceanographic conditions or to related effects on prey; however, interannual variability versus seasonal variability in distribution cannot be distinguished from these data.

There was a striking coherence during July 1997 between the distribution of large whales and the coccolithophore bloom on the middle shelf (Fig. 5). Harbor porpoises were also prevalent in the coccolithophore bloom waters within the eastern and central middle shelf strata (see middle shelf definitions in 'Materials and methods') of the SEBS (Fig. 7). During July 1997, whales therefore were not most numerous at the slope region of highest chlorophyll $a$, but rather occurred on the middle shelf in association with the most productive water on the shelf (Fig. 4). 

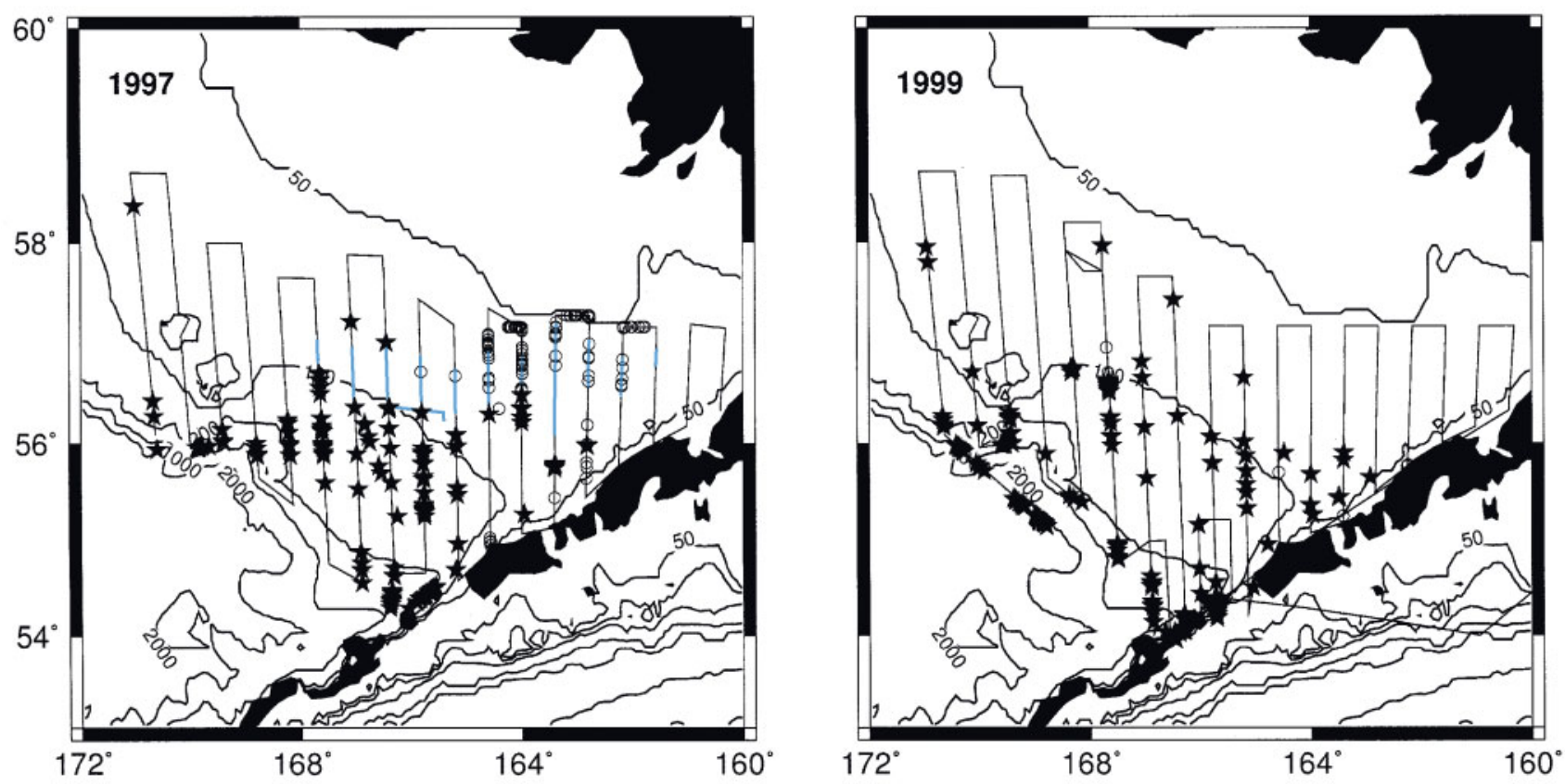

Fig. 7. Phocoenoides dalli and Phocoena phocoena. Distribution of sightings of Dall's porpoise ( $\star$ ) and harbor porpoise (०) in the SE Bering Sea from July 17 to August 5, 1997 and June 10 to July 2, 1999. Extent of a coccolithophore bloom in 1997 is shown by blue lines

\section{Small cetaceans}

Dall's porpoise was the most numerically dominant small cetacean in the surveyed region of the SEBS. Dall's porpoises were more abundant in the central middle shelf and outer shelf domains in July 1997 than in June 1999 (Tables 2 \& 3, Fig. 7). Abundances on the slope were similar in both years; however, the small area of basin-edge ( $>2000 \mathrm{~m}$ ) habitat surveyed in 1999 proved to support a higher density of Dall's porpoises (2.068 porpoise $\mathrm{km}^{-2}$ ) than any other stratum (Table 3, Fig. 7). The combined shelf and slope regions surveyed in 1997 supported a total of $27268(\mathrm{CV}=0.28)$ Dall's porpoises (Table 2). The combined shelf, slope and basin-edge estimate of Dall's porpoise abundance for the SEBS in June 1999 was 32303 (CV=0.21) (Table 3). The highest densities occurred in the slope and basin-edge regions in 1997 and 1999 (Tables 2 \& 3, Fig. 7); however, the highest abundances in 1997 occurred in the central middle shelf (163.7 to $\left.168.1^{\circ} \mathrm{W}\right)$ and outer shelf in $1997(\mathrm{~N}=9409$, $\mathrm{CV}=0.38$; and $\mathrm{N}=9283, \mathrm{CV}=0.60$, respectively), due to the larger shelf areas of these domains relative to the slope region (Tables $2 \& 3$ ). As was the case with large whales, Dall's porpoises were less abundant in the western middle shelf $\left(168.1\right.$ to $\left.171.1^{\circ} \mathrm{W}\right)$ than in the central middle shelf $\left(163.7\right.$ to $\left.168.1^{\circ} \mathrm{W}\right)$ (Tables $2 \& 3$, Fig. 7). The higher densities of Dall's porpoises in deeper strata support the biogeographical paradigm that these cetaceans are important top-trophic denizens of deeper, outer shelf and basin regions.
In contrast to the distribution of Dall's porpoises, harbor porpoises were restricted to the middle shelf and shallower coastal inner shelf domains in 1997 $(\mathrm{N}=16885, \mathrm{CV}=0.27$ ) (Table 2, Fig. 7). The clear weather and calm sea during July (i.e. Beaufort 0 to 3 from July 19 to 24) contributed to the excellent sighting conditions for this species. In comparison, higher sea states in June 1999 reduced the detection of harbor porpoises; therefore, only for 1997 are reliable density and abundance estimates available. Harbor porpoises were the most numerically abundant small cetacean in the eastern ( 160.3 to $\left.163.7^{\circ} \mathrm{W}\right)$ and central (163.7 to $168.1^{\circ} \mathrm{W}$ ) strata of the SEBS middle shelf in 1997: $\mathrm{N}=5508(\mathrm{CV}=0.32)$ and $\mathrm{N}=11377(\mathrm{CV}=$ 0.34), respectively (Table 2, Fig. 7). Harbor porpoises appeared to confine their distribution to shelf regions $<100 \mathrm{~m}$ deep, or north of the Middle Front $(\sim 100 \mathrm{~m}$ isobath). Along the middle shelf, harbor porpoises did not occupy the western middle shelf (168.1 to $\left.171.1^{\circ} \mathrm{W}\right)$ but concentrated in the region east of $165^{\circ} \mathrm{W}$ (Fig. 7).

\section{Consumption estimates}

During the summer of 1997, it is estimated that 513 fin whales $(\mathrm{CV}=0.61)$ on the central middle shelf (163.7 to $168.1^{\circ} \mathrm{W}$ ) consumed 61560-172368 metric tons (mt) of prey, equivalent to $65 \%$ of the prey consumed by fin whales in all surveyed shelf and slope 
regions combined (95 280-266 $784 \mathrm{mt}$ prey) (Table 2). An estimated 1308 humpback whales $(\mathrm{CV}=0.65)$ on the central middle shelf consumed approximately 127 922-345312 mt of prey in 1997, an amount representing $76 \%$ of the total prey consumed by humpback whales in all surveyed shelf and slope regions (169 194-456 $720 \mathrm{mt}$ prey) (Table 2). When combined, fin and humpback whales on the central middle shelf accounted for $72 \%$ of the prey consumption by these species on the surveyed regions of the SEBS shelf and slope. During 1999, consumption of prey by 938 fin whales $(\mathrm{CV}=0.54)$ on the central middle shelf (112560-315 $168 \mathrm{mt}$ prey) accounted for $79 \%$ of all prey consumed by fin whales in the surveyed shelf, slope and basin-edge regions (142 080-397 $824 \mathrm{mt}$ prey) (Table 3).

The estimate for the amount of prey consumed by fin and humpback whales on the central middle shelf of the SEBS in 1997 (189482-517580 mt prey, Table 2) ranges up to 1 order of magnitude greater than the amount of prey consumed by all Dall's porpoises (49082 $\mathrm{mt}$ prey) in the shelf and slope (Tables 2 \& 3) and 2 orders of magnitude greater than the amount of prey consumed by harbor porpoises on the middle shelf of the SEBS (1520-6585 mt, Table 2).

\section{Shelf carbon transferred to atmosphere by whales}

Fin whales and humpback whales that forage in the SEBS during summer ultimately transfer large amounts of carbon (C), on the order of $20 \times 10^{3}$ to $50 \times 10^{3} \mathrm{mt} \mathrm{C}$ from the shelf system to the atmosphere, especially those whales that forage on the middle shelf (Tables 2 \& 3). Specifically, during 1997, respiration by fin whales and humpback whales contributed 7146-20009 mt C and 12690-34254 mt C, respectively, to the atmosphere. Fin whales and humpback whales that foraged on the central middle shelf contributed $\sim 65$ and $76 \%$, respectively, of the total carbon transferred to the atmosphere by each species. During 1999, fin whales transferred 10656-29837 mt C to the atmosphere, of which approximately $80 \%$ was transferred by whales which foraged on the central middle shelf. Respiration by these 2 species therefore represents a significant loss of carbon from the SEBS shelf system, especially from the middle shelf, to the atmosphere.

\section{Shelf carbon egested by whales}

Egestion of carbon by whales represents an important pathway of carbon recycling in the shelf system in which they forage. Through egestion, fin and humpback whales in the surveyed region of the SEBS shelf and slope during 1997 returned 6612-18087 mt C to the ecosystem. During the summer of 1997 , egestion by fin whales and humpback whales which foraged on the middle shelf returned approximately 1782-4989 $\mathrm{mt}$ and 3773-10183 $\mathrm{mt} \mathrm{C}$, respectively, to the shelf (Table 2). For the middle shelf, this represents a total recycling of approximately 5555-15172 mt C in the pelagic system by these 2 species during summer 1997. During 1999, egestion by fin whales which foraged in the middle shelf returned approximately 2832-7929 $\mathrm{mt} \mathrm{C}$ to the shelf (Table 3). Fin whales were 1 order of magnitude more abundant on the middle shelf than in other SE shelf domains during the late 1990s and, consequently, their ecological role in carbon transfer and cycling was magnified in this shelf domain. Humpback whales, which were most numerous in the middle shelf in July 1997 but were rare in this same region in June 1999, exhibited either stronger seasonal (i.e. monthly) or interannual variability in their shelf distribution. Hence, their regional influence in the cycling and transfer of carbon appears more variable.

\section{DISCUSSION}

\section{Changes in the SE Bering Sea shelf ecosystem}

The North Pacific and Bering Sea have undergone decadal-scale changes in physical forcing (Overland et al. 1999) and regime shifts in ecological response (Francis \& Hare 1994, Mantua et al. 1997, Francis et al. 1998). In terms of atmospheric forcing, August SSTs in the 1990s were approximately $1^{\circ} \mathrm{C}$ warmer than in the 1960s (Bond \& Adams 2002). The climate of the 1990s included about $10 \mathrm{~W} \mathrm{~m}^{-2}$ more atmospheric heating from mid-May through July compared to the 1960s; this resulted in SSTs $\sim 1^{\circ} \mathrm{C}$ warmer in spring and early summer of the 1990s than in previous decades (Bond \& Adams 2002). It is during these decadal climatic changes that the ecological impacts of some recovering populations of whales have increased.

High interannual variability in wind forcing and Sverdrup transport (Bond et al. 1994), extent and retreat of sea ice (Overland \& Pease 1982, Niebauer \& Day 1989), and timing and development of the spring bloom (Hunt \& Stabeno 2002) also characterize the eastern Bering Sea. During the El Niño of 1997, unusual atmospheric forcing and oceanic response in the SEBS (Overland et al. 2001, Stabeno et al. 2001) were coincident with anomalies in nutrients, phytoplankton, and some zooplankton species compared with the 1980s (Napp \& Hunt 2001, Stockwell et al. 2001). Further, the development in 1997 of an extensive 
bloom of the coccolithophore Emiliania huxleyi in the anomalously warm water may have altered trophic pathways and the carbon cycle on the shelf. The reoccurrence of the coccolithophore blooms, as confirmed by direct sampling in 1998 (Iida et al. 2002), 1999 (Olson \& Strom 2002) and 2000 (Iida et al. 2002), as well as by SeaWiFS imagery (i.e. SeaWiFS Project, NASA/Goddard Space Flight Center), suggests a longer-term ecological shift in the phytoplankton community of the eastern shelf.

Amid the oceanographic and ecosystem anomalies of 1997, it was difficult to determine whether the large numbers of fin whales and humpback whales on the middle shelf of the SEBS represented another ecosystem anomaly, or whether the pattern reflected a longer-term redistribution of large whale biomass in the system (Tynan 1999). The surveys of 1999 provided the first interannual comparison of whale distribution in the SEBS, and indicated that the distribution of foraging whales, especially fin whales, on the middle shelf during the late 1990s represented a longer-term pattern. In addition, a continuation of this survey in June 2000 (Moore et al. 2002) further confirmed that fin whales and humpback whales were more numerous on the middle shelf than the outer shelf of the SEBS. During summer, whales on the southeast middle shelf reside in a region characterized by weak $(\leq 1 \mathrm{~cm}$ $\mathrm{s}^{-1}$ ) mean along-shelf flow toward the WNW, moderately energetic tidal currents of $\sim 30$ to $35 \mathrm{~cm} \mathrm{~s}^{-1}$ (Coachman 1986, Stabeno et al. 2001), lower incidence of storms compared to outer shelf and basin regions (Overland \& Pease 1982), and disappearance of seasonal ice cover (Niebauer \& Day 1989). During June 1999, fin whales and right whales must have moved onto the middle shelf soon after the retreat of the ice. Cold surface waters $\left(4\right.$ to $\left.6^{\circ} \mathrm{C}\right)$ near the Aleutians may have deterred humpbacks from entering the middle shelf, where a 2 to $6^{\circ} \mathrm{C}$ surface layer over a $1^{\circ} \mathrm{C}$ cold pool occurred. Temperatures of $<4^{\circ} \mathrm{C}$ in the Southern Ocean, however, do not prevent migratory humpback whales from occurring close to the ice edge and important oceanographic features (Tynan 1997).

Despite the anomalies of the late 1990s, no significant interannual differences in the biomass of euphausiids or zero-age pollock occurred on the inner shelf of the SEBS (Coyle \& Pinchuk 2002a). Data to assess taxon-specific interannual variability in midtrophic levels on the middle shelf are fewer than on the inner shelf in the late 1990s, where programs such as the Inner Front program targeted their efforts. Where comparable sampling exists for the middle shelf, the abundances of adult plus juvenile euphausiids are similar for the late 1990s and early 1980s (Stockwell et al. 2001). Increased biomass of some other mid-trophic planktonic taxa on the middle shelf did occur during the 1990s. The biomass of gelatinous zooplankton on the middle shelf was 1 order of magnitude higher during the 1990s than during the previous decade, indicating a possible regime change around 1990 (Brodeur et al. 1999). The middle-shelf summer concentrations of older copepodite stages of Calanus marshallae were also 1 order of magnitude greater during the late 1990s than during the early 1980s (Tynan et al. 2001). Spring concentrations of numerically abundant copepods (Acartia spp., C. marshallae, and Pseudocalanus spp.) also increased significantly between the early 1980s and the late 1990s (Napp et al. 2002). The increased production of C. marshallae is 1 factor that may explain why a remnant population of North Pacific right whales now predictably occupies the middle shelf during summer (Tynan et al. 2001). Multispecies interactions in a copepod-based food web (Springer \& Roseneau 1985) may have altered with the development of the coccolithophore blooms and the increased production of some copepod species and jellyfishes on the shelf.

\section{Evidence for decadal changes in whale abundance and distribution}

A shift in the center of the summer distribution of large whales in the SE Bering Sea, from the slope during the 1950s-1960s to the middle shelf by the late 1990s, may have begun during the mid-1970s. To interpret the pattern and timing of change, it is useful to examine the few large-whale surveys conducted in the 1970s and 1980s. Sighting surveys then found very few large whales in the SEBS, suggesting that the center of distribution of those remaining whales may have already shifted from the slope to the shelf (see Kawamura 1975).

Of the relatively small number of large whales sighted in the SEBS shelf, slope and Aleutian 'neritic' region during Kawamura's 1974 survey $(715$ miles surveyed: Kawamura 1975), minke whales were the most abundant species and accounted for $68 \%$ of the sightings. The distribution of the identified large whales was as follows: 3 minke whales on the SEBS shelf of outer Bristol Bay; 2 minke, 4 fin, and 2 humpback whales in the Bering, 'neritic' zone (which appears from Kawamura's [1975] Fig. 1 to be north of the Aleutians between 165 and $170^{\circ} \mathrm{W}$ ); and 12 minke and 2 fin whales over the SEBS shelf and slope. Therefore, there is some suggestion that although the slope was still an important region for minke whales during the mid1970 s, shallower shelf regions $(<200 \mathrm{~m}$ depth) were important to recovering populations of fin and humpback whales. Although neither the sighting survey methods nor the geographic coverage from Kawa- 
mura's 1974 survey are directly comparable to those reported here for the late 1990s, the 1974 encounter rates in the SEBS of 0.008 fin whales nautical mile ${ }^{-1}$ and 0.0028 humpback whales nautical mile ${ }^{-1}$ are 1 order of magnitude lower than those for the late 1990s. In addition, off Nunivak Island in 1975, Nemoto (1978) noted the rarity of humpback whales within the continental shelf.

A series of 8 semi-seasonal aerial surveys conducted during 1982 to 1983 by Leatherwood et al. (1983) across Bristol Bay and the eastern Bering Sea (south of $62^{\circ} \mathrm{N}$ and east of $174^{\circ} \mathrm{W}$ ) shelf, slope, and basin, also attested to the rarity of large whales. Leatherwood et al.'s (1983) survey area of $632732 \mathrm{~km}^{2}$ included the historically productive whaling ground for fin whales, which was centered over basin, slope and outer shelf regions between $53-56^{\circ} \mathrm{N}$ and $165-171^{\circ} \mathrm{W}$ from 1954 to 1962 (Nasu 1963); Leatherwood et al. found no fin whales in this historically important region. Of particular note was the 'almost complete absence of (fin whale) sightings in blocks 4 , 5 , and $6^{\prime}$ (the strata that correspond to the center of fin whale distribution during the 1950s). In 1982 only 5 fin whales were sighted by Leatherwood et al. (1983) in the SEBS east of $171^{\circ} \mathrm{W}$. These whales were all in water $<110 \mathrm{~m}, 2$ of them in Bristol Bay, 2 on the middle shelf and 1 north of Pribilof Canyon. Only 2 sightings of humpback whales were recorded during the 1982 aerial surveys. Although the survey methodology used in the July-August 1982 aerial surveys of the SEBS is not directly comparable to the ship-based surveys of the late 1990s, the encounter rate for fin whales in $1982\left(<0.0016\right.$ fin whales $\mathrm{km}^{-1}$; Leatherwood et al. [1983]) is again 1 order of magnitude less than that for the total area of the SEBS surveyed in 1997 (0.03 fin whales $\mathrm{km}^{-1}$ ) and 1999 (0.02 fin whales $\mathrm{km}^{-1}$ ). Although no large-scale cetacean survey data exist for the late 1980s and early 1990s, Baretta \& Hunt (1994) noticed a regional increase in the frequency of cetacean sightings near the Pribilof Islands in the late 1980s compared with the mid-1970s.

In contrast to the paucity of whales on the shelf in the early 1980s, there were $1308(\mathrm{CV}=0.65)$ humpbacks and $513(\mathrm{CV}=0.61)$ fin whales in the 'central' stratum of the SE middle shelf in July 1997, and 938 $(\mathrm{CV}=0.54)$ fin whales in the same region in June 1999. Clearly, between the early 1980s and late 1990s whale abundance on the SEBS shelf had increased; the middle shelf has become an important summer foraging ground for fin, humpback, and right whales. The center of the summer ecological impact of large whales in the SEBS ecosystem (east of $171^{\circ} \mathrm{W}$ ) therefore appears to have shifted from the slope during the mid-20th century to the middle shelf by the end of the century.

\section{Ecological implications of altered whale distributions}

Although the majority of whale biomass in the SEBS (160.32 to $171.08^{\circ} \mathrm{W}$ ) may have been associated with the shelf-edge and slope regions until the 1950s to 1960s, it clearly shifted by the late 1990s to the middle shelf. Despite the high productivity typically found at the shelf-break (Springer et al. 1996) and the high chlorophyll ( 2 to $33 \mathrm{\mu g} \mathrm{l}^{-1}$ ) still found in this region during our surveys in the late 1990s, there was no whale biomass-peak evident. The distribution of whales implies that secondary production and, consequently, the density of zooplankton or smaller forage fishes, is higher on the middle shelf than elsewhere. It has been shown that whales need to encounter a critical threshold of prey density to make their foraging energetically worthwhile (Brodie et al. 1978, Piatt \& Methven 1992, Kenney \& Wishner 1995). Therefore it appears from the cetacean distributions in the late 1990s that prey density and availability on the middle shelf should have exceeded that elsewhere. That fin whales returned to the middle shelf in 1997 and 1999 suggests that whales were attracted to a region of predictably high prey density.

That the middle shelf supported the highest abundance of whales, such as fin whales (which feed on fishes, euphausiids, or copepods), humpback whales (which feed on euphausiids or schooling fishes), and North Pacific right whales (which target late-stage copepodites of calanoid copepods) is evidence that more than one prey taxon was more available. In the SEBS, near-surface swarms of euphausiids were rarely reported on the inner shelf in August-September 1997 (Stockwell et al. 2001); however, further offshore on the middle shelf $(\sim 75 \mathrm{~m})$ we witnessed brown oval surface swarms of euphausiids at $56^{\circ} 45.14^{\prime} \mathrm{N}$, $165^{\circ} 12.81^{\prime} \mathrm{W}$, on 24 July 1997 . The euphausiid surface swarms occurred in the aqua-colored bloom of Emiliania huxleyi in conditions of SST $=11.7^{\circ} \mathrm{C}$ and surface salinity $=31.548$. Spatial and interannual variability of euphausiid biomass for the entire SEBS shelf during the late 1990s is unknown. However, our records of surface patches in the vicinity of sei and humpback whales, as well as our observations of numerous feeding flocks of short-tailed shearwaters Puffinus tenuirostris (see also Hunt et al. 1996), suggest that euphausiids were present on the middle shelf.

Although the abundance of North Pacific right whales is very low (i.e. tens of whales), it does appear that this remnant population also prefers to forage on the middle shelf in stratified water south of the Inner Front (Tynan et al. 2001). Collections of zooplankton made near right whales in 1997 and 1999 confirm that the abundance of Calanus marshallae CIII, CIV, and CV copepodites in the late 1990s is 1 order of 
magnitude higher on the middle shelf than during the PROBES era (1976 to 1981) (Tynan et al. 2001). Stockwell et al. (2001) also reported higher mean concentrations of some copepod species on the middle shelf in June 1997 than during the early 1980s. Spring concentrations of numerically abundant copepods were also significantly higher during 1994 to 1998 than 1980 to 1981 (Napp et al. 2002). Smith \& Vidal (1986) proposed that increased temperature enhances the number of herbivores (e.g. zooplankton) on the middle shelf during a warm year. Temperature alone however does not appear to explain the increase in copepod production in the late 1990s. Although the anomalously warm conditions during the summer of 1997 would support a thermal theory, high concentrations of CIII and CIV C. marshallae also occurred on the middle shelf during a colder year (1999) (Tynan et al. 2001). This was not the case on the inner shelf, where calanoid abundance was reduced during a cold year (June 1999) compared to that in the warm conditions of 1997 (Coyle \& Pinchuk 2002b). The extent and timing of sea-ice arrival and retreat also varied between the 2 years (Stabeno et al. 2002). High zooplankton biomass on the middle shelf during summer may depend on the spatial and temporal availability of food encountered by earlier ontogenetic life stages during spring as a consequence of ice and spring bloom dynamics. Predation by whales on planktivorous fishes might also reduce predation pressure on some zooplankton taxa.

Due to regional differences in cross-shelf and alongshelf variability in circulation and prey availability, whales in the central or western Bering Sea would not be expected to experience the same shelf-partitioning as whales occupying the SEBS. For example, in the central Bering Sea shelf west of the Pribilof Islands $\left(171.43\right.$ to $\left.178.92^{\circ} \mathrm{W}\right)$, fin whales occur primarily near the $200 \mathrm{~m}$ isobath and near canyons (Moore et al. 2000). The circulation and ecological dynamics at shelf-breaks associated with canyons (Schoenherr 1991) may relate to the occurrence of some whales near the shelf-break in the central Bering Sea. Within the SEBS, the middle shelf exhibits some along-shelf variability in physical structure and nutrient supply during summer which could affect along-shelf variability in the ecosystem. Along the $70 \mathrm{~m}$ isobath (the center of the middle shelf), 3 zones are evident during summer: a cold pool in the southeast (typically centered at $\sim 57^{\circ} \mathrm{N}$, but absent in 1997), with more uniform replenishment of nutrients; an intermediate zone, consisting of warmer water, with weaker stratification; and a northern cold pool northward of the Pribilof Islands, where nutrient replenishment is more episodic (Stabeno et al. 2002). The latter may partially explain why chlorophyll was much lower in the middle shelf north of the Pribilof Islands $\left(<0.5 \mu \mathrm{g} \mathrm{l}^{-1}\right)$ than in more eastern sectors of the middle shelf ( 0.5 to $2.0 \mu \mathrm{g} \mathrm{l}^{-1}$ ) during summer. Whales and harbor porpoises prefer to forage in the more productive southeast and intermediate zones of the SE middle shelf than in the NW sector. In addition to having higher surface chlorophyll, the preferred foraging regions had warmer SSTs than the NW sector, and included the origin region of the coccolithophore bloom in 1997.

Theoretical studies suggest that the range of prey preference by a top predator can eliminate chaos, dampen oscillations and even produce point stability in a previously oscillatory system (Post et al. 2000). For the cetacean species discussed here, specific trophic pathways and predator-prey interactions in the present shelf ecosystem need definition; however, the numerically abundant fin and humpback whales on the SEBS shelf have, historically, shown a wide range of prey preferences (See 'Introduction'), linking them with the dynamics of multiple food chains. Complex feedback loops in the partitioning of carbon between pelagic and benthic communities would depend on prey preferences by top predators under a given set of ocean conditions. For example, during a warm year, when grazing by calanoid copepods is far more efficient at removing primary production (Coyle \& Pinchuk 2002b), the consumption of planktivorous fishes by whales could reduce predation pressure on some zooplankton taxa (e.g. calanoid copepods), thereby increasing the carbon flux to zooplankton and lessening that available to the benthos. Alternatively, the direct consumption of zooplankton by whales could reduce the amount of prey available to fishes and seabirds, reduce the grazing efficiency of zooplankton to remove primary production, and increase the flux of carbon to benthic communities.

\section{Ecological consequences of the increased whale populations}

The ecological consequences of large whales present over the middle shelf include altered pathways, partitioning, and cycling of carbon and nutrients in pelagic and benthic systems: (1) an increase of predation on mid-trophic levels (zooplankton and fishes) in the middle shelf relative to other domains; (2) enhanced interspecific competition between planktivorous and piscivorous upper-trophic species, provided that the availability of their zooplankton and fish prey is truly limiting; (3) remineralization of prey biomass on the middle shelf; (4) seasonal sequestration of carbon in whale biomass and consequent export of carbon from the shelf system during the fall whale migration; (5) loss of respired carbon to the atmosphere. In the Southern Ocean, top predators have been considered a 
major leak in the biological carbon pump, transferring as much as 20 to $25 \%$ of the photosynthetically-fixed carbon to the atmosphere (Huntley et al. 1991). Even this estimate was for a system in which whales had been depleted. The $\mathrm{CO}_{2}$ ultimately respired by fin and humpback whales that concentrate on the SEBS shelf each summer (e.g. 20000-50 $000 \mathrm{mt} \mathrm{C}$ as reported here) may represent an inefficiency of the shelf to serve as a carbon sink. By comparison, during 1997, egestion by fin and humpback whales that foraged on the middle shelf returned 5555-15172 mt C to the pelagic system. The fraction of the egested carbon available to the benthos is unknown; however, benthic biomass is directly influenced by the quality and quantity of organic carbon deposited to the benthos (Grebmeier et al. 1988). Both the amounts of carbon ultimately respired or egested by the whales are larger than the amount of carbon transported offshore in the California Current System by a meandering jet (e.g. $2400 \mathrm{t}$ per event) (Barth et al. 2002). Further, during their intensive summer feeding activity, humpback and fin whales can add at least 50 and $30 \%$ to their body mass, respectively (Lockyer 1981). Therefore, the migration of large whales and other cetaceans from the eastern Bering Sea shelf each fall also represents an important seasonal export or loss of carbon, nutrients, and energy from the shelf. Given that the biological export of shelf carbon is an important sink of the global $\mathrm{CO}_{2}$ cycle (Walsh et al. 1981), the off-shelf transport of carbon in whale biomass is an important flux.

Due to increased numbers, some large whales (i.e. fin whales) have had greater ecological impact in the late 1990s compared to previous decades; however, models of carbon and energy flow have failed to incorporate this top-trophic influence. In their models of the Bering Sea shelf system during the late 1970s (1976 to 1981), Walsh \& McRoy (1986) assumed that pelagic top-trophic levels such as fin whales, seals, and surface-feeding birds, were present in the outer shelf, where they removed carbon. Whales, which were rare in the shelf system at that time, were not included in the carbon model for the middle shelf, although avian apex predators were incorporated (e.g. murres, kittiwakes and shearwaters) (Walsh \& McRoy 1986). Much has changed in the lower, mid-trophic and uppertrophic communities since the early 1980s. Then, the middle shelf was described as primarily a benthic system where herbivore abundance was relatively low, a large amount of algal production remained ungrazed and sank to the seafloor (Smith \& Vidal 1986, Walsh \& McRoy 1986), the biomass of the macrobenthic infauna was 10 times greater than on the outer shelf (Haflinger 1981) and, consequently, the middle shelf supported the greatest abundance of benthic predators such as yellowfin sole Pleuronectes aspera and other small flat- fishes (Bakkala 1993). By the late 1990s it was the middle shelf and not the outer shelf that supported the highest number of fin whales in the SEBS. Problems still exist with most ecosystem models of the eastern Bering Sea that lack ecological roles of cetaceans (Trites et al. 1999). Although forage fishes such as pollock $(<30 \mathrm{~cm})$, capelin $(\sim 15 \mathrm{~cm})$, and Pacific herring (up to $25 \mathrm{~cm}$ ) were the main fish species consumed by fin whales from 1952 to 1958 in the northern North Pacific and Bering Sea (Nemoto 1959), the specific prey preferences of fin and humpback whales on the middle shelf of the SEBS during the late 1990s are unknown. Therefore, their role in structuring the relative trophic pathways involving forage fishes versus groundfishes will remain obscure until their prey preferences are defined.

The amount of prey consumed by large whales on the SEBS shelf $\left(160.32\right.$ to $\left.171.08^{\circ} \mathrm{W}\right)$ during summer can represent a measurable fraction of mid-trophic level biomass. The estimates of prey biomass consumed by fin and humpback whales on the SEBS shelf and slope in 1997 (264 474-723 504 mt) are equivalent to $10-27 \%$ of the total 1997 echo-integration trawl (EIT) biomass estimate of walleye pollock (2.59 million mt, see Ianelli et al. 2002) for the entire eastern Bering Sea shelf region between Unimak Pass and the US-Russia Convention line. When comparison is restricted to east of $170^{\circ} \mathrm{W}$ (where cetaceans and pollock were surveyed from the same ship), the estimates of prey biomass consumed by fin and humpback whales in 1997 are equivalent to $34-94 \%$ of the EIT-derived biomass estimate of walleye pollock ( 0.773 million $\mathrm{mt}$, see Ianelli et al. 2002). This does not imply that whales are consuming such an amount of pollock, but rather places the magnitude of their consumption of fishes or zooplankton in relation to the biomass of a dominant fish species. Unfortunately, no similar synoptic estimate of zooplankton biomass exists for the SEBS shelf during the late 1990s. If whales consume pollock, it is likely that the smallest size classes (i.e. age 0 to 1 ) are typically targeted. Although it appears unlikely that the fin whales on the SE middle shelf were targeting pollock as prey during colder conditions of June 1999, we cannot define specific trophic linkages between mid- and upper trophic levels without new, directed research on predator-prey interactions and their interannual variability on the eastern Bering Sea shelf. The question of variable predation pressure on juvenile pollock and other fishes by top-trophic levels in different shelf domains needs to be reexamined with the new data on cetacean abundances. Switches in targeted prey of fin and humpback whales may occur between cold and warm years, as well as over longerterm regime shifts; however, these specific responses are unknown. Nonetheless, conceptual models exam- 
ining hypotheses of bottom-up versus top-down regulation of the pelagic ecosystem (Hunt et al. 2002) should consider top-down regulation by cetaceans.

The ecological role of small cetaceans on the shelf also warrants re-evaluation with the new estimates of abundance and distribution. Although fin and humpback whales consume an order of magnitude more prey biomass than Dall's porpoises or harbor porpoises on the SEBS shelf, their roles as top predators vary with shelf domain and with prey preferences. Dall's porpoises are important denizens of the outer shelf, slope and basin-edge domains, where their prey probably consists of fishes and squid (Fiscus \& Jones 1999, Ohizumi et al. 2000). In the southern Sea of Okhotsk, walleye pollock (size range 60 to $601 \mathrm{~mm}$ fork length) was the third most abundant prey item consumed by Dall's porpoises (Walker 1996). With their distribution and highly diverse food habits, the ecological role of Dall's porpoises in the SEBS is greater seaward of the Middle Front than shoreward of it. Conversely, the penetration by harbor porpoises into deeper water on the middle shelf terminates approximately where the shallowest penetration of Dall's porpoises begins. The trophic implications of the ecological roles of these 2 porpoise species therefore shifts at approximately the $80 \mathrm{~m}$ isobath of the middle shelf. In addition, the number of harbor porpoises on the SE middle shelf in 1997 $(\mathrm{N}=16885 ; \mathrm{CV}=0.27)$ was several times greater than the number of harbor porpoises reported by Dahlheim et al. (2000) from aerial surveys across the coastal inner shelf and Bristol Bay in 1997 ( $\mathrm{N}=3531,95 \% \mathrm{CI}=2206$ to 5651). Harbor porpoises, often considered coastal denizens, can extend their distribution well onto the middle shelf (and westward to $165^{\circ} \mathrm{W}$ ) in certain years, especially so perhaps in warm years such as 1997 , when they were present during the coccolithophore bloom. There, during summer, they can become locally important denizens of the top-trophic community, consuming 1520-6585 mt of prey (e.g. schooling, smoothrayed fishes; Kastelein et al. 1997). While their impact as consumers may appear small compared to that of whales, small cetaceans can become locally important predators in the SEBS.

\section{CONCLUSIONS}

From the results of line-transect surveys in the southeastern Bering Sea (160.32 to $\left.171.08^{\circ} \mathrm{W}\right)$, it was found that large-whale abundance was highest on the middle shelf $(50<\mathrm{z}<100 \mathrm{~m})$ during summer in the late 1990s. From the abundance and distribution of fin and humpback whales, it is apparent that the ecological role of these top-trophic predators in the shelf system has increased since the late 1970s and early 1980s, espe- cially on the middle shelf. The presence of foraging whales on the southeastern middle shelf in the late 1990s also contrasts with their distribution during the 1950s to 1960s when the peak in whale biomass was centered over the shelf-edge, slope $(180<\mathrm{z}<2000 \mathrm{~m})$ and basin $(>2000 \mathrm{~m})$ regions. This shift in the center of large whale biomass in the southeastern Bering Sea is suggested primarily by the recurrence of fin whales on the middle shelf during the late 1990s. The presence of large whales in the middle shelf during the late 1990s suggests that high secondary production in this domain is capable of supporting high whale biomass. Therefore, the presence of large numbers of baleen whales in the middle shelf of the southeastern Bering Sea during the late 1990s introduces a far greater influence of top-level predators in the system, with important trophic consequences for altered pathways of carbon and energy flow on the middle shelf.

Given the important role of cetaceans in structuring the Bering Sea ecosystem (National Research Council 1996), research is needed to define the modern trophic linkages between cetaceans and their prey. As the distributions of whales are closely coupled to prey availability, specific process-oriented studies are needed in the vicinity of foraging fin and humpback whales to quantify the density and abundance of their preferred fish and zooplankton prey. In addition, analyses of blubber fatty acids, which have been useful in investigating the diet and spatial scales of foraging marine mammals (Borobia et al. 1995, Iverson et al. 1997), might also elucidate differences in trophic positions for fin and humpback whales. With modern definition of species-specific prey preferences, ecosystem modelers should then strive to incorporate these recent estimates of cetacean abundance in spatially and temporally explicit pelagic and benthic food webs that stratify trophic linkages, carbon and energy flow through top predators by shelf or hydrographic domains. This is especially important in view of the massive coccolithophore blooms that may have altered trophic dynamics in the eastern Bering Sea. Finally, models that include modern estimates of cetacean populations and their roles in the structure and function of shelf ecosystems will vastly improve our understanding of the importance of top predators to the stability of marine communities.

Acknowledgements. The officers and crew of the RV 'Miller Freeman' were very helpful in the successful completion of the surveys. The expertise and dedication of the observers R. Pitman, R. Rowlett, L. T. Pusser and S. Sinclair were invaluable to the quality of the sightings data. The Alaskan Fisheries Science Center (AFSC) and the Southwest Fisheries Science Center provided equipment for the surveys; J. Laake (AFSC) provided generous assistance with program DISTANCE and J. Napp (AFSC) supplied shipboard and labora- 
tory facilities for chlorophyll analyses. D. G. Ainley, R. Brodeur, P. Dayton, J. A. Estes, J. Lerczak, A. M. Springer and 3 anonymous reviewers provided helpful comments on earlier versions of the manuscript. This research was supported by grants to C.T.T. from the Office of Protected Resources, Recover Protected Species Program, NOAA, and the North Pacific Marine Research Initiative. Institutional support was derived from the Joint Institute for the Study of the Atmosphere and Ocean (JISAO), University of Washington; the Northwest Fisheries Science Center and AFSC, NOAA; and the Woods Hole Oceanographic Institution, where as such this publication represents WHOI Contribution No. 10909. G. Stauffer, N. Williamson and C. Wilson supported the integration of mammal surveys within the hydroacoustic surveys of pollock conducted by AFSC. This publication is dedicated in memory of Jim Traynor, a NOAA scientist who first welcomed the inclusion of cetacean surveys in conjunction with the pollock survey in 1997.

\section{LITERATURE CITED}

Ainley DG, DeMaster DP (1990) The upper trophic levels in polar marine ecosystems. In: Smith WO Jr (ed) Polar oceanography, Part B: Chemistry, biology, and geology. Academic Press, San Diego, p 599-630

Bakkala RG (1993) Structure and historical changes in the groundfish complex of the Eastern Bering Sea. NOAA Tech Rep NMFS 114, U.S. Dept Commerce

Baretta L, Hunt GL Jr (1994) Changes in the numbers of cetaceans near the Pribilof Islands, Bering Sea, between 1975-78 and 1987-89. Arctic 47:321-326

Barth JA, Cowles TJ, Kosro PM, Shearman RK, Huyer A, Smith RL (2002) Injection of carbon from the shelf to offshore beneath the euphotic zone in the California Current. J Geophys Res 107:10.1029/2001JC000956

Baum JK, Myers RA, Kehler DG, Worm B, Harley SJ, Doherty PA (2003) Collapse and conservation of shark populations in the Northwest Atlantic. Science 299:389-391

Benson SR, Croll DA, Marinovic BB, Chavez FP, Harvey JT (2002) Changes in the cetacean assemblage of a coastal upwelling ecosystem during El Niño 1997-98 and La Niña 1999. Prog Oceanogr 54:279-291

Bond NA, Adams JM (2002) Atmospheric forcing of the southeast Bering Sea shelf during 1995-99 in the context of a 40-year historical record. Deep-Sea Res Part II 49:5869-5887

Bond NA, Overland JE, Turet P (1994) Spatial and temporal characteristics of the wind forcing of the Bering Sea. J Climate 7:1119-1130

Borobia M, Gearing PJ, Simard Y, Gearing JN (1995) Blubber fatty acids of finback and humpback whales from the Gulf of St. Lawrence. Mar Biol 122:341-353

Bowen WD (1997) Role of marine mammals in aquatic ecosystems. Mar Ecol Prog Ser 158:267-274

Brodeur RD, Mills CE, Overland JE, Walters GE, Schumacher JD (1999) Evidence for a substantial increase in gelatinous zooplankton in the Bering Sea, with possible links to climate change. Fish Oceanogr 8:296-306

Brodie PF, Sameoto DD, Sheldon RW (1978) Population densities of euphausiids off Nova Scotia as indicated by net samples, whale stomach contents, and sonar. Limnol Oceanogr 23:1264-1267

Brown SG, Lockyer CH (1984) Whales. In: Laws RM (ed) Antarctic ecology, Vol 2. Academic Press, London, p 717-781

Buckland ST, Anderson DR, Burnham KP, Laake JL, Borchers DL, Thomas L (2001) Introduction to distance sampling. Oxford University Press, Oxford
Coachman LK (1986) Circulation, water masses, and fluxes on the southeastern Bering Sea shelf. Cont Shelf Res 5:23-108

Cooney RT (1981) Bering Sea zooplankton and micronekton communities with emphasis on annual production. In: Hood DW, Calder JA (eds) The eastern Bering Sea shelf: oceanography and resources, Vol 2. US Dept of Commerce, NOAA, Office of Marine Pollution Assessment, Seattle, WA, p 947-974

Cooney RT, Coyle KO (1982) Trophic implications of crossshelf copepod distributions in the southeastern Bering Sea. Mar Biol 70:187-196

Coyle KO, Pinchuk AI (2002a) The abundance and distribution of euphausiids and zero-age pollock on the inner shelf of the southeast Bering Sea near the Inner Front in 1997-1999. Deep-Sea Res Part II 49:6009-6030

Coyle KO, Pinchuk AI (2002b) Climate-related differences in zooplankton density and growth on the inner shelf of the southeastern Bering Sea. Prog Oceanogr 55:177-194

Croll DA, Tershy BR, Hewitt RP, Demer DA and 8 others (1998) An integrated approach to the foraging ecology of marine birds and mammals. Deep-Sea Res Part II 45:1353-1371

Dahlheim M, York A, Towell R, Waite J, Breiwick J (2000) Harbor porpoise (Phocoena phocoena) abundance in Alaska: Bristol Bay to southeast Alaska, 1991-1993. Mar Mamm Sci 16:28-45

Estes JA, Tinker MT, Williams TM, Doak DF (1998) Killer whale predation of sea otters linking oceanic and nearshore ecosystems. Science 282:473-476

Fiedler PC, Reilly SB, Hewitt RP, Demer D and 6 others (1998) Blue whale habitat and prey in the California Channel Islands. Deep-Sea Res Part II 45:1781-1801

Fiscus CH, Jones LL (1999) A note on cephalopods from the stomachs of Dall's porpoises (Phocoenoides dalli) from the Northwestern Pacific and Bering Sea, 1978-1982. J Cetacean Res Manage 1:101-107

Francis RC, Hare SR (1994) Decadal-scale regime shifts in the large marine ecosystems of the North-east Pacific: a case for historical science. Fish Oceanogr 3:279-291

Francis RC, Hare SR, Hollowed AB, Wooster WS (1998) Effects of interdecadal climate variability on the oceanic ecosystems of the NE Pacific. Fish Oceanogr 7:1-21

Frost KJ, Lowry LF (1981) Foods and trophic relationships of cetaceans in the Bering Sea. In: Hood DW, Calder JA (eds) The eastern Bering Sea shelf: oceanography and resources, Vol 2. US Dept of Commerce, NOAA, Office of Marine Pollution Assessment, Seattle, WA, p 825-836

Grebmeier JM, McRoy CP, Feder HM (1988) Pelagic-benthic coupling on the shelf of the northern Bering and Chukchi Seas. I. Food supply source and benthic biomass. Mar Ecol Prog Ser 48:57-67

Haflinger K (1981) A survey of benthic infaunal communities of the southeastern Bering Sea. In: Hood DW, Calder JA (eds) The eastern Bering Sea shelf: oceanography and resources, Vol 2. US Dept of Commerce, NOAA, Office of Marine Pollution Assessment, Seattle, WA, p 1091-1104

Hood DW (1981) Introduction. In: Hood DW, Calder JA (eds) The eastern Bering Sea shelf: oceanography and resources, Vol 1. US Dept of Commerce, NOAA, Office of Marine Pollution Assessment, Seattle, WA, p 13-18

Hunt GL Jr, Stabeno PJ (2002) Climate change and the control of energy flow in the southeastern Bering Sea. Prog Oceanogr 55:5-22

Hunt GL Jr, Burgeson B, Sanger GA (1981) Feeding ecology of seabirds of the eastern Bering Sea. In: Hood DW, Calder JA (eds) The eastern Bering Sea shelf: oceanography and resources. Vol 2, US Dept of Commerce, NOAA, Office of Marine Pollution Assessment, Seattle, WA, p 629-647 
Hunt GL Jr, Coyle KO, Hoffman S, Decker MB, Flint EN (1996) Foraging ecology of short-tailed shearwaters near the Pribilof Islands, Bering Sea. Mar Ecol Prog Ser 141: $1-11$

Hunt GL Jr, Baduini CL, Brodeur RD, Coyle KO and 8 others (1999) The Bering Sea in 1998: the second consecutive year of extreme weather-forced anomalies. EOS Trans Am Geophys Union 81(47):561-566

Hunt GL Jr, Stabeno P, Walters G, Sinclair E, Brodeur RD, Napp JM, Bond NA (2002) Climate change and control of the southeastern Bering Sea pelagic ecosystem. Deep-Sea Res Part II 49:5821-5853

Huntley ME, Lopez MDG, Karl DM (1991) Top predators in the Southern Ocean: a major leak in the biological carbon pump. Science 253:64-66

Ianelli J, Fritz L, Honkalehto T, Williamson N, Walters G (2000) Eastern Bering Sea walleye pollock stock assessment. In: Stock assessment and fishery evaluation report for the groundfish resources of the Bering Sea/Aleutian Islands regions. North Pacific Fishery Management Council, Anchorage, AK, Appendix A, p 39-212

Ianelli JN, Barbeaux S, Honkalehto T, Walters G, Williamson N (2002) Eastern Bering Sea walleye pollock stock assessment. North Pacific Fishery Management Council, Anchorage, AK, Appendix A, p 33-120 (see also www.afsc. noaa.gov/refm/docs/2002/BSpollock.pdf

Iida T, Saitoh SI, Miyamura T, Toratani M, Fukushima $H_{\text {, }}$ Shiga N (2002) Temporal and spatial variability of coccolithophore blooms in the eastern Bering Sea, 1998-2001. Prog Oceanogr 55:165-175

Iverson SJ, Frost KJ, Lowry LF (1997) Fatty acid signatures reveal fine scale structure of foraging distribution of harbor seals and their prey in Prince William Sound, Alaska. Mar Ecol Prog Ser 151:255-271

Kastelein RA, Hardeman J, Boer H (1997) Food consumption and body weight of harbour porpoises (Phocoena phocoena). In: Read AJ, Wiepkema PR, Nachtigall PE (eds) The biology of the harbour porpoise. De Spil, Woerden, The Netherlands, p 217-233

Kawamura A (1971) Influence of chasing time to stomach contents of baleen and sperm whales. Sci Rep Whales Res Inst 23:27-36

Kawamura A (1975) Whale distribution in Bering Sea and northern North Pacific in the summer of 1974: results of a visual sighting study aboard the University of Hokkaido training vessel Oshoro Maru. Bull Jpn Soc Fish Oceanogr 25:119-128

Kawamura A (1982) Food habits and prey distributions of three rorqual species in the North Pacific Ocean. Sci Rep Whales Res Inst 34:59-91

Kenney RD, Wishner KF (1995) The South Channel ocean productivity experiment. Cont Shelf Res 15:373-384

Kenney RD, Scott GP, Thompson TJ, Winn HE (1997) Estimates of prey consumption and trophic impacts of cetaceans in the USA northeast continental shelf ecosystem. J Northwest Atl Fish Sci 22:155-171

Klumov SK (1961) Plankton and the feeding of baleen whales (Mystacoceti). Trudy Instituta Okeanologii 51:142-156

Klumov SK (1963) Food and helminth fauna of whalebone whales (Mystacoceti) in the main whaling regions of the world ocean. Trudy Instituta Okeanologii 71:94-194

Laake JL, Buckland ST, Anderson DR, Burnham KP (1994) DISTANCE user's guide V.2.1. Colorado Cooperative Fish \& Wildlife Research Unit, Colorado State University, Fort Collins

Leatherwood S, Bowles AE, Reeves RR (1983) Endangered whales of the eastern Bering Sea and Shelikof Strait,
Alaska; results of aerial surveys, April 1982 through April 1983 with notes on other marine mammals seen. Tech Rep no. 83-159. Hubbs-Sea World Res Inst, San Diego

Lockyer C (1981) Growth and energy budgets of large baleen whales from the Southern Hemisphere. FAO Fish Ser 3(5): 379-487

Lowry LF, Frost KJ (1981) Feeding and trophic relationships of phocid seals and walruses in the eastern Bering Sea. In: Hood DW, Calder JA (eds) The eastern Bering Sea shelf: Oceanography and resources, Vol 2. University of Washington Press, Seattle, p 813-824

Macaulay MC, Wishner KF, Daly KL (1995) Acoustic scattering from zooplankton and micronekton in relation to a whale feeding site near Georges Bank and Cape Cod. Cont Shelf Res 15:509-537

Mantua NJ, Hare SR, Zhang Y, Wallace JM, Francis RC (1997) A Pacific interdecadal climate oscillation with impacts on salmon production. Bull Am Meteorol Soc 78: 1069-1079

Moore SE, Waite JM, Mazzuca LL, Hobbs RC (2000) Mysticete whale abundance and observations of prey associations on the central Bering Sea shelf. J Cetacean Res Manage 2:227-234

Moore SE, Waite JM, Friday NA, Honkalehto T (2002) Cetacean distribution and relative abundance on the central-eastern and the southeastern Bering Sea shelf with reference to oceanographic domains. Prog Oceanogr 55:249-261

Myers RA, Worm B (2003) Rapid worldwide depletion of predatory fish communities. Nature 423:280-283

Napp JM, Hunt GL Jr (2001) Anomalous conditions in the south-eastern Bering Sea 1997: linkages among climate, weather, ocean, and biology. Fish Oceanogr 10:61-68

Napp JM, Baier CT, Brodeur RD, Coyle KO, Shiga N, Mier K (2002) Interannual and decadal variability in zooplankton communities of the southeast Bering Sea shelf. Deep-Sea Res Part II 49:5991-6008

Nasu K (1963) Oceanography and whaling ground in the subarctic region of the Pacific Ocean. Sci Rep Whales Res Inst 17:105-155

Nasu K (1974) Movement of baleen whales in relation to hydrographic conditions in the northern part of the North Pacific Ocean and the Bering Sea, Chapter 16. In: Hood DW, Kelley EJ (eds) Oceanography of the Bering Sea with emphasis on renewable resources, Institute of Marine Science, University of Alaska, Fairbanks, AK, p 345-361

National Research Council (1996) The Bering Sea ecosystem. National Academy Press, Washington, DC

Nemoto T (1959) Food of baleen whales with reference to whale movements. Sci Rep Whales Res Inst 14:149-290 + Plate 1

Nemoto T (1963) Some aspects of the distribution of Calanus cristatus and $C$. plumchrus in the Bering and its neighbouring waters, with reference to the feeding of baleen whales. Sci Rep Whales Res Inst 17:157-170

Nemoto T (1978) Humpback whales observed within the continental shelf waters of the eastern Bering Sea. Sci Rep Whales Res Inst 30:245-247

Niebauer HJ, Day RH (1989) Causes of interannual variability in the sea ice cover of the eastern Bering Sea. GeoJournal 18.1:45-59

Ohizumi H, Kuramochi T, Amano M, Miyazaki N (2000) Prey switching of Dall's porpoise Phocoenoides dalli with population decline of Japanese pilchard Sardinops melanostictus around Hokkaido, Japan. Mar Ecol Prog Ser 200: 265-275

Olson MB, Strom SL (2002) Phytoplankton growth, microzoo- 
plankton herbivory and community structure in the southeast Bering Sea: insight into the formation and temporal persistence of an Emiliania huxleyi bloom. Deep-Sea Res Part II 49:5969-5990

Omura H, Ohsumi S, Nemoto T, Nasu K, Kasuya T (1969) Black right whales in the North Pacific. Sci Rep Whales Res Inst 21:1-78 + Plates 1-18

Overland JE, Pease CH (1982) Cyclone climatology of the Bering Sea and its relation to sea ice extent. Mon Weather Rev Am Meteorol Soc 110:5-13

Overland JE, Adams JM, Bond NA (1999) Decadal variability of the Aleutian Low and its relation to high-latitude circulation. J Climate 12:1542-1548

Overland JE, Bond NA, Adams JM (2001) North Pacific atmospheric and SST anomalies in 1997: links to ENSO? Fish Oceanogr 10:69-80

Palka DL, Hammond PS (2001) Accounting for responsive movement in line transect estimates of abundance. Can J Fish Aquat Sci 58:777-787

Pauly D, Christensen V, Dalsgaard J, Froese R, Torres F Jr (1998) Fishing down marine food webs. Science 279: 860-863

Piatt JF, Methven DA (1992) Threshold foraging behavior in baleen whales. Mar Ecol Prog Ser 84:205-210

Post DM, Conners ME, Goldberg DS (2000) Prey preference by a top predator and the stability of linked food chains. Ecology 81:8-14

Ridgway SH (1966) Dall porpoise, Phocoenoides dalli (True): observations in captivity and at sea. Norsk HvalfangstTidende 5:97-110

Schoenherr JR (1991) Blue whales feeding on high concentrations of euphausiids around Monterey submarine canyon. Can J Zool 69:583-594

Schumacher JD, Stabeno PJ (1998) Continental shelf of the Bering Sea. Chapter 27. In: Robinson AR, Brink KH (eds) The Sea, Vol 11. John Wiley \& Sons, New York, p 789-822

Sergeant DE (1969) Feeding rates of Cetacea. Fiskeridir Skr Ser Havunders 15:246-258

Smith SL, Vidal J (1986) Variations in the distribution, abundance, and development of copepods in the southeastern Bering Sea in 1980 and 1981. Cont Shelf Res 5:215-239

Springer AM, Roseneau DG (1985) Copepod-based food webs: auklets and oceanography in the Bering Sea. Mar Ecol Prog Ser 21:229-237

Springer AM, McRoy CP, Flint MV (1996) The Bering Sea green belt: shelf-edge processes and ecosystem production. Fish Oceanogr 5:205-223

Springer AM, Piatt JF, Shuntov VP, Van Vliet GB, Vladimirov VL, Kuzin AE, Perlov AS (1999) Marine birds and mammals of the Pacific subarctic gyres. Prog Oceanogr 43: 443-487

Springer AM, Estes JA, van Vliet GB, Williams TM, Doak DF, Danner EM, Forney KA, Pfister B (2003) Sequential megafaunal collapse in the North Pacific Ocean: an ongoing legacy of industrial whaling? Proc Natl Acad Sci USA 100:12223-12228

Stabeno PJ, Bond NA, Kachel NB, Salo SA, Schumacher JD (2001) On the temporal variability of the physical environ-

Editorial responsibility: Otto Kinne (Editor),

Oldendorf/Luhe, Germany ment over the south-eastern Bering Sea. Fish Oceanogr 10:81-98

Stabeno PJ, Kachel NB, Sullivan M, Whitledge TE (2002) Variability of physical and chemical characteristics along the 70-m isobath of the southeastern Bering Sea. DeepSea Res Part II 49:5931-5943

Stockwell DA, Whitledge TE, Zeeman SI, Coyle KO, Napp JM, Brodeur RD, Pinchuk AI, Hunt GL Jr (2001) Anomalous conditions in the south-eastern Bering Sea, 1997: nutrients, phytoplankton and zooplankton. Fish Oceanogr 10:99-116

Tønnessen JN, Johnsen AO (1982) The history of modern whaling. University of California Press, Berkeley

Trites AW, Livingston PA, Mackinson S, Vasconcellos MC, Springer AM, Pauly D (1999) Ecosystem change and the decline of marine mammals in the eastern Bering Sea: testing the ecosystem shift and commercial whaling hypotheses. Fisheries Centre Research Report, Fisheries Centre,University of British Columbia 7:106

Tynan CT (1997) Cetacean distributions and oceanographic features near the Kerguelen Plateau. Geophys Res Lett 24: $2793-2796$

Tynan CT (1998) Ecological importance of the southern boundary of the Antarctic Circumpolar Current. Nature 392:708-710

Tynan CT (1999) Redistributions of cetaceans in the southeast Bering Sea relative to anomalous oceanographic conditions during the 1997 El Niño. PICES Sci Reptort No. 10: $115-117$

Tynan CT, DeMaster DP, Peterson WT (2001) Endangered right whales on the southeastern Bering Sea shelf. Science 294:1894

van Franeker JA, Bathmann UV, Mathot S (1997) Carbon fluxes to Antarctic top predators. Deep-Sea Res Part II 44: $435-455$

Vance TC, Schumacher JD, Stabeno PJ, Baier CT and 11 others (1998) Aquamarine waters recorded for the first time in the Eastern Bering Sea. EOS Trans Am Geophys Union 79:122-126

Walker WA (1996) Summer feeding habits of Dall's porpoise, Phocoenoides dalli, in the southern Sea of Okhotsk. Mar Mamm Sci 12:167-181

Walsh JJ, McRoy CP (1986) Ecosystem analysis in the southeastern Bering Sea. Cont Shelf Res 5:259-288

Walsh JJ, Rowe GT, Iverson RL, McRoy CP (1981) Biological export of shelf carbon is a sink of the global $\mathrm{CO}_{2}$ cycle. Nature 291:196-201

Wishner KF, Schoenherr JR, Beardsley R, Chen C (1995) Abundance, distribution and population structure of the copepod Calanus finmarchicus in a springtime right whale feeding area in the southwestern Gulf of Maine. Cont Shelf Res 15:475-507

Zenkovich BA (1969) Whales and plankton in Antarctic waters. In: Arsenev VA, Zenkovich BA, Chapskii KK (eds) Marine mammals. Izdatel'stvo Nauka, Moscow, p 150-152

Zenkovich BA (1970) Whales and plankton in Antarctic waters. In: Holdgate MW (ed) Antarctic ecology. Academic Press, London, p 183-185

Submitted: March 18, 2003; Accepted: February 5, 2004

Proofs received from author(s): May 6, 2004 